\title{
KADININ KUTSAL ANLATILARA KARŞI MÜCADELESİ: DALGALARI AŞMAK FİLMİNDE KADIN MESİH FİG̈̈R̈̈
}

\author{
Uğur Baloğlu
}

\begin{abstract}
Öz
Uygarlık tarihinde kadının erkek karşısında ikincil pozisyonda resmedilmesi ile dini anlatılar arasında derinlikli bir ilişki mevcuttur. Feminist teoloji, bu derinlikli ilişkiyi açığa çıkarmak ve yok etmek için bir fırsat sunarak kimi zaman linguistik çerçevede var olan söylemsel yapıları bozar, kimi zaman da dini figürlerin alternatiflerini düşündürmeyi amaçlar. Dini figürlerin sinema sanatı aracılığıyla yeniden üretimi süregelen tartışmalara katkıda bulunur. Ancak yapılan tartışmalar incelendiğinde din, felsefe, mitoloji, feminizm ve sinema arasında kurulan ilişki bağlamında kadın sorunlarına bütünleyici bir yaklaşımın eksikliği gözlenmektedir. Bu çalışma, kutsal anlatılarda ve söylenlerde var olan ataerkil tahakkümü tartışmaya açarak Batı tektanrılı dini geleneklerini ve uygulamalarını feminist çerçevede yeniden değerlendiren feminist teolojik yaklaşımla Breaking the Waves (Dalgaları Aşmak, Lars von Trier, 1996) filmindeki kadın Mesih figürüne odaklanır. Filmdeki karakterlerin eylem ve söylemlerinin Hıristiyan teoloji ile kurduğu ilişki ve kadın Mesih figürü, feminist teoloji üzerinden tematik analiz yöntemiyle incelenir. Çalışmada, kadın Mesih figürünün olanaklılığının eril tahakkümün belirleyici sınırları çerçevesinde yapılandırıldığı sonucuna ulaşılmıştır.
\end{abstract}

Anahtar Sözcükler: Kadın Mesih, feminist teoloji, ataerkil söylem, eril tahakküm, kutsal, kurban, kurtarıcı. 


\title{
THE STRUGGLE OF WOMAN AGAINST HOLY NARRATIVES: THE FEMALE CHRIST FIGURE IN BREAKING THE WAVES
}

\begin{abstract}
In the history of civilization, there is a deep relationship between religious narratives and portrayals of women in positions that are secondary to men. Feminist theology tends to disrupt discursive structures and may suggest alternative religious figures by revealing and destroying this deep relationship. The portrayal of religious figures through the art of cinema contributes to an ongoing discussion. When the discussion is examined, one can observe the lack of a complementary approach to the problems of women in the context of religion, philosophy, mythology, and cinema. This article discusses the paternalistic domination found in religious narratives, then focuses on the female Christ figure in Breaking the Waves, adopting a feminist-theological approach that reinterprets Western monotheistic traditions. It also examines the relationship between the film's characters and Christian theology, embodied particularly in the figure of a female Christ. It concludes with a recognition that the figure of a female Christ is structured within the boundaries of male domination.
\end{abstract}

Keywords: Female Christ, feminist theology, patriarchal discourse, male domination, holy, martyr, savior. 


\section{Giriş}

Kültürel çalışmalar alanında toplumsal cinsiyet üzerine yapılan tartışmalar 1960'lı ylllar sonrasında artmaya başlamıştır. Yaklaşık elli yıllık bir süreç içinde erkek egemen düşüncenin baskısı altında haklarını arayan ve seslerini duyurmaya çalışan kadınlar, yüzyılın son çeyreğinde seslerini yükselterek dünyanın birçok yerinde protesto eylemlerinde bulunmuştur. Özellikle 1980 sonrası dönemde yeni milliyetçi-muhafazakâr anlayışın yükselişe geçmesi ve günümüzde siyasal iktidarların bu anlayış çerçevesinde şekillenmesi kadınların toplumsal yaşam içinde örgütlenmelerini zorunlu kılmaktadır. 2016'nın sonlarında Donald Trump'ın ABD başkanı olduktan sonra yaptığı cinsiyetçi açıklamalara karşı bir araya gelen kadınlar eşzamanlı gösteriler düzenleyerek ırkçılık, cinsiyetçilik, yoksullaştıran ekonomi politikaları gibi farklı konularda tepkilerini ortaya koymuştur. 2017'de ABD'de başlayan bu büyük dalga sonrasında 8 Mart'ın ortak bağlayıcılığıyla dünyanın birçok yerinde hatta Olağanüstü Hal'in devam ettiği Türkiye'de bile eylemler devam etmiştir. Gösterilerin hemen hepsinde kadın-erkek arasında eşitsizliğin devam ettiği tüm alanlara karşı mücadele verilmiştir.

Kadın hakları mücadele tarihi, ilk uygarlıklar tarafından yaratılan mitlerden günümüze değin uzanan oldukça geniş bir süreci kapsar. Yahudi geleneği içinde sözü edilen Adem'in ilk karısı Lilith'in erkek egemenliğine baş kaldırışı kadın hakları mücadelesinin ilk örneğini verir. Yahudi mitolojisine Sümer anlatılarından geçtiği ileri sürülen Lilith, Adem ile eşit koşullarda yaratıldığı için onun isteklerine ve otoritesine boyun eğmeyip cenneti kendi isteği ile terk eder. ${ }^{1}$ Eski Yahudi anlatılarında hakkını arayan bir özne olarak betimlenen Lilith, tarihsel süreçte bu özelliğini yitirerek şeytanlaştırılır ve Antik Çağ, Orta Çağ ve modern yüzyılda kadının erkek kontrolünde olmasının temel dayanağı olarak gösterilir. ${ }^{2}$

1 Havva'dan önce yaratılan ilk kadın olan Lilith'in erkeğe boyun eğmez tavrı feminist çalışmalarda öncül olarak gösterilir. Ancak ataerkil söylem içinde mitolojide kötülüğün anası olarak tanımlanması ve doğurgan, besleyen ana tanrıça mitine yüklenen pozitif anlamı tersine çeviren bir özelliği içinde barındırması, dişilliğin bereket simgesinden koparılıp erkekleri doğru yoldan saptıran şehvet ve tutku içinde kötülüğe çeken negatif anlam yüklü bir figüre dönüşmesine neden olmuştur (Alphabet of Ben Sira 78: Lilith).

2 Gila Stopler, Batı medeniyetinde Lilith'in sonradan şeytanlaştırıldığını ileri sürer. Hatta bu şeytanlaştırmayı günümüz cinsiyet eşitsizliğinin yeniden üretiminin nedenlerinden biri olarak niteler (2005, s. 47). Ayrıca konu ile ilgili detaylı bilgi için Stephanie Irene Spoto'nun (2012) doktora tezi incelenebilir. 
Dinin belirleyici bir unsur olarak kültürün yaşam alanına sızması, insanların geçmişten gelen kutsal değerlerini dokunulmaz kılmalarını sağlar. Böylece dini anlatılar kültürel yaşam içinde bireysel davranışlarla katılaşıp, düşünmeden gerçekleştirilen eylemlere ve tabulara dönüşerek ataerkil toplumsal düzenin devamlılığı sağlanır. Modern toplumsal yaşam içinde erkek ve kadın rolleri de bu gelenekselleşmiş rollerin içselleştirilmiş yansımalarını oluşturur. Émile Durkheim, ideal kavramı ile dinsel sistemlerin içinde var olan sembolleri niteleyerek, bunların toplumlarda ahlaki duyguları ve ortak bilinci oluşturmayı sağladığına vurgu yapar (Smith, 2007, s. 25). Yaratılan bu ortak bilinç, geçmişten bugüne geleneksel bağlarla kuvvetlendirilmiş, mevcudiyeti kutsal olan ile meşru kllınmış ataerkil düzenin içinde varlığını sürdüren günümüzdeki hâkim söylemi niteler.

Tarihsel süreçte düşüncelerimizi belirleyen söylemsel yapı bütün kurumların -ekonomi, siyaset, hukuk, din- etkisi ve etkileşimi ile birlikte oluşur. Ancak bu kurumsal yapılar içinde bireyin yaşamına doğrudan müdahale eden, onu sınırlayan, davranışlarını ve bakış açılarını oluşturan, bu bakımdan bireyin düşünsel yapısını etkileyen dini kurumlar ve dini söylemlerin etkisini incelemek önemlidir. Zira din, toplumsal devamlılığın sağlanması için gerekli bir model olup insanların içinde yaşadığı toplumsal sistemi anlamalarına da yardımcı olur (Mardin, 1990, s. 40) ve böylece bireyin kendini içsel -manevi- yönden tümlemesi din ile mümkün olabilmektedir. Bu bakımdan uygarlığın başlangıcından itibaren insanın doğayı anlamlandırma çabası olarak nitelendirilen dinin, insan ve toplum ile kurduğu ilişkiyi anlayabilmek günümüzde kadın-erkek eşitsizliğinin çözümü için yol gösterici olacaktır. Nitekim mitolojik söylemlerde ve tektanrılı dinlerde kadının erkekle aynı hak ve özgürlüklere sahip olmadığı, kadınlara karşı önyargılı bir bakış açısının olduğu yazılı belgelerde mevcuttur. ${ }^{3}$ Hıristiyan teolojisi ise kilisenin koyduğu kurallar çerçevesinde bu önyargılı bakış açısını üreten gelenekselleştirilmiş davranış ve düşüncelerle, ataerkil ideolojinin kadınları nesneleştiren ve erkeklere hizmet etmelerini meşrulaştıran bir araca dönüşür.

3 Konu ile ilgili detaylı araştırma için Sue Blundell'in (1995) ufuk açıcı çalışması, yüzyıllardır Antik Yunan tarihini erkek egemen bir dünya çerçevesinde okunduğunu ve bu dünyada kamusal alanın dışında tutulan kadınların günlük deneyimlerini anlatmaktadır. Çalışmada erkeklerin kadınlara atfettiği roller dönemin kültürel yaşamı göz önünde tutularak resmedilmektedir. Tektanrılı dinlerde kadının konumu ile ilgili detaylı bilgi için bkz. (Berktay, 2000). 
Çalışma, dindeki ataerkil tahakkümü tartışmaya açıp feminist teolojik yaklaşımla dini figürlerin alternatiflerini reel toplumsal düzlemi estetik bağlamda temsil eden sinema yoluyla ele almayı amaçlamaktadır. Sinema filmleri bir dünyayı tasvir etmekle kalmayıp aynı zamanda bir dünya görüşü geliştirdiğinden (Lyden, 2000, s. 433) ve reel toplumsal yaşamın bir yansımasını oluşturduğundan kuramsal çerçevede tartışılan kavramlar; sinemasında dini tartışan, eleştiren ve bu eleştiriyi kadın karakterler üzerinden yapan Lars von Trier'nin Altın Kalp üçlemesinin ${ }^{4}$ ilk filmi üzerinden ele alınmıştır. Buna göre tektanrılı dinlerdeki geleneksel kadın-erkek ilişkilerinde erkek egemen söylemin eleştirisi yapılarak dini figürlerin erkek temsillerinin yerinden edilip kadın temsillerinin inşasının olanaklılığı Dalgaları Aşmak (Breaking The Waves, 1996) filmindeki kurban, kutsal ve kurtarıcı temaları ile yapılandırılan karakterin eylem ve söylemleri üzerinden feminist teoloji bağlamında tematik analiz yöntemiyle sorgulanmıştır. Tematik analiz, niteliksel bir analiz türüdür. Verileri ayrıntılı bir şekilde gösterir ve farklı konularla yorumlama yoluyla ilgilenir (Boyatzis, 1998, s. IX-4). Yorumları kullanarak keşfetmeyi amaçlayan herhangi bir çalışma için en uygun yöntem kabul edilen tematik analiz yöntemi, kelime ve cümle saymanin ötesine geçerek hem örtük hem de açık fikirleri tanımaya ve tanımlamaya odaklanır (Alhojailan, 2012, s. 10).

\section{Eril Dilde Kadın İnşası}

İnsanın nesne konumundan sıyrllip hayatın öznesi olması ve bununla birlikte düşünen bir birey haline gelmesi ile birlikte kadın hak, özgürlük ve eşitlik istemlerinin giderek artması Batıda modern düşüncenin kurumsallaşmasıyla mümkün olur. Ancak yüzyıllardır erkek karşısında ikinci planda tutulan kadının bu mücadeleye rağmen hâlâ aynı konumda kalması nasıl açıklanabilir? 1789 Fransız Devrimi ile birlikte gündeme gelen özgürlük ve eşitlik kavramları kadın hak ve özgürlüklerinin gelişmesine / genişlemesine neden etki etmemiştir? Konu ile ilgili birçok sav ileri sürülmekle birlikte modernliğin dini kurumları tasfiye ettiği ve modern toplumsal yaşamda dinin etkisinin giderek azaldığı yönünde düşünceler mevcuttur. Zira Fransız Devrimi'nin aslında kadın hakları içinde doğrudan olmasa da yarar sağlayacağına; kadınlar erkeklere ekonomik ve

4 Üçlemenin diğer filmleri Idioterne (1998) ve Dancer in The Dark'tır (2000). Lars von Trier'ye göre Altın Kalp üçlemesindeki her film, şeytani -kötü- bir dünyada iyi bir kadını betimler. Yönetmen, üçlemesinde kadınların din, ahlak, toplum baskısı gibi birçok nedenden dolayı boğulan iyi varlıklar olduğunu belirtir (Brinkman, 2013, s. 81). 
toplumsal anlamda bağımlı yaşadıklarından erkeğin toplumsal hayattaki konumunun düzelmesi ile birlikte kadının da konumunun düzeleceğine inanılmaktaydı (Nye, 1988, s. 5). Ancak devrim sonrası kurumsal değişimlerin erkek otoritesine dayanan bir örgütlenme düzeni çerçevesinde gerçekleşmesi, kadın haklarının geçmişte olduğu gibi yok sayılmasına neden olmuştur. Zira geleneksel kültürel kodların geçmişten günümüze din ile birlikte harmanlanıp kalıplaşmış davranış biçimleri oluşturduğu göz ardı edilmektedir. ${ }^{5}$

Kadının hak ettiği konuma ulaşması için yapılan çalışmalar Aydınlanma sonrası felsefi düşünceyi dayanak yapan çalışmalarla temellenir. Aydınlanmanın insan düşüncesinde kırılma noktası olarak belirlenmesi gelenek ve modern arasında düşünsel farklılaşmayı daha net ortaya koymayı sağlayabilir. Zira Batı'da kurumlaşmış Kilise'yi ve söz sahibi olduğu dönemi eleştiren ve reformist hareketlerle yıkan bu düşünce yapısı, aynı zamanda Hıristiyanlığın bir eleştirisini yapar. Bu bağlamda toplumsal yaşamda problemli olan alanların dinle ilişkisi daha net ortaya çıkar. Bu problemlerden biri de kadının toplumsal yaşam içindeki rolüdür. Dinin yorumlanmasında kadının eksik-insan olarak nitelenmesi kadının toplumdaki rolünü belirleyen en temel referans noktası gibi görünür. Ancak bu referans noktasının temeli dinlerden önce mitolojik söylenler ve ilk dönem felsefi düşüncede karşımıza çıkar. Bu nedenle bu söylenlerin ve felsefi düşüncenin incelenmesi öncelikli olarak gereklidir.

\section{Androsentrik Felsefede Kadın}

İlk dönem filozofları üzerine çalışmalar yapan Kathleen Wider (1986) ve

5 Kadın-erkek arasındaki eşitsizliği üreten diğer bir alan ise özel mülkiyetin erkek egemenliğinin altında olmasıdır. Uygarlık ile birlikte sınırları belli bir toprakta yaşayan toplumda, erkeğin toprak üzerinde (diğer anlamı ile doğa yani doğurgan ana) güç sahibi olması; bu gücü artırmak için savaş ve evlilikler yoluyla toprak birleşimini sağlayarak kadını ve toprağı ele geçirilen ve alınıp satılabilen, takas edilebilen bir ürüne dönüştürmeleri toplumsal yaşamda kadının giderek erkek karşısında gücünün yitmesine neden olur. Konu ile ilgili Friedrich Engels, Ailenin, Özel Mülkiүetin ve Devletin Kökeni (1979) adlı çalışmasında, tarihte kadının ikincil pozisyonda resmedilmesinin ekonomik nedenlerini açıklar. Buna göre, kadın hakları mücadelesinde eşitliğin sağlanabilmesi ilkin özel mülkiyetin ortadan kaldırılabilmesi ile mümkündür. Aynı şekilde 1919 yılında proleter kadın hareketinin Sovyetler Birliği'ndeki görevleri hakkında konuşma yapan Lenin, kadın hakları mücadelesinde Batı Avrupa'daki kadınların başarılı olamamasını ekonomi politik nedenlere bağlayarak kapitalizmin ve özel mülkiyetin bulunduğu yerde erkek üstünlüğünün olduğunu vurgular (Marx, Engels \& Lenin, 1992, s. 182). 
felsefe tarihinin erkek filozoflar tarihi olduğunu düşünen Ingeborg Gleichauf'un (2007, s. 9) çalışmaları kadının androsentrik söylem içinde yok sayıldığını belirtir. Kadının doğurganlığını doğa ile ilişkisi üzerinden kadınların doğayı taklit etmesi olarak yorumlayan Platon (ö. 347 MÖ), diğer çalışmalarında aklın erkek ruhuna daha uygun olduğunu varsayar. İdealar dünyası ile erkek aklı arasında kurulan bu örtük bağ gelecek yıllarda erkek aklın üstünlüğünün kurulmasına ön ayak olur. Zira ruh-beden, rasyonel-irrasyonel gibi ikili karşıt kavramlar Platon sonrası dönemde yeniden yorumlanarak özellikle tektanrılı dinlerde erkeğin kadın üzerinde tahakkümüne dayanak noktası oluşturur (Lyold, 1996, s. 22-26).

İdealar dünyasının erilliğinin Platon'un fikirleriyle yerleşmesinin ardından Aristoteles (ö. 322 MÖ), Platon'dan bir kuşak sonra, Politika adlı eserinde kadınların evlerindeki geleneksel rollerine geri dönmeleri gerektiğini yazar. Doğada erkek ve kadının eşit olmadığını, cinsiyet açısından erkeğin doğasını üstün, kadınınkini ise aşağı olarak niteler (Aristotle, 2013). ${ }^{6}$ Aristoteles'e göre erkek, yönetici konumda iken kadın yönetene uyması gereken bir nesne olarak belirlenir. Böylece Antik Yunan felsefesinin kurucuları tarafından erkekler, aklın doğal simgesi olarak nitelenirken kadınlar, akıl tarafından yönetilmesi gereken bedeni ve tutkuları simgeleyerek bilginin nesnesi konumuna itilir.

Kadının tarih boyunca felsefe alanında öteki olarak konumland1rılması, felsefenin tektanrılı dinlerle etkileşime geçip farklılaşması ile derinleşir. Edwin Hatch, Huristiyan geleneğin Grek felsefesine dayand1ğını ve orada üretilen fikirlerin Hıristiyan dünyasının geçmişi ve şimdisi arasında süreklilik arz ettiğini söyler (1897, s. 5). Bu bakışla, erkek egemen görüşlerin felsefe alanında baskınlığı din ve felsefenin tanışması sonrası kökleşir. Antik Yunan felsefesinde erkek-kadın arasında kurulan karşıtlık ve akıl-beden ikiliği dini düşüncede Âdem-Havva mitiyle yeniden yorumlanır. Özellikle Ortaçağ'da Kilise'nin kurumlaşmasıyla birlikte erkek ve kadın arasında kurulan birincil-ikincil konumlandırma Hıristiyan geleneğinde devam eder. Bu cinsiyetçi yaklaşımı, Platon ve Aristoteles'in görüşlerinden temellenen Batı felsefe geleneğinde de görmek mümkündür. Zira Descartes'ın (ö. 1650) kartezyen düalizmi insanı zihin

6 Kadının tarih boyunca felsefe alanının dışında, toplumsal yaşam içinde ikincil ya da aşağı konumda tutulduğunu gösteren ve bunu felsefi metinlerle destekleyip günümüz modern felsefesinin ve modern toplumsal yaşamın düşünsel kırılımını oluşturduğunu gösteren birçok araştırma mevcuttur. Bkz. (Duby, \& Perrot, 2005; Blundell, 1995; De Beauvoir, 2011; Woolf, 2012; Millett, 2011; Berktay, 2003). 
ve beden olarak iki kategoriye ayırır ve zihin Ben, beden ise Ben'in ötekisi olarak konumlanır. Antik Yunan'daki ikili karşıtlıklar zemininin uzantısı olarak yorumlanabilecek olan kartezyen düşünce günümüz modern toplumlarda hâlâ var olan cinsiyetler arası kopuşu derinleştirir. Descartes, "Antik Çağ düşünürleri gibi, eril zihni tanrısallık ve Ruh ile ilişkilendirir ve Ruh'un yalnızca insanın Tanrı ile paylaştığı niteliklerden oluştuğunu söyler. Böylece, Batı düşünce geleneği, 17. yüzyılda da Bilgi ve Aklı, bedenin 'kirleticiliğinden', maddeden ve dişil olan her şeyden uzak tutmak" geleneğini devam ettirir (Berktay, 2000, s. 145). Gelenek ve modern düşünce arasında kırılma yaratan Aydınlanma felsefesi, modern yaşamın kapılarını aralayıp din, siyaset, ekonomi gibi kurumlarda köklü değişimlere olanak sağlar. Ancak Aydınlanma'nın yarattığı bu köklü değişimi kadın düşüncesinde bulmak mümkün değildir. Örneğin, Fransız Devrimi'ni düşünceleriyle doğrudan etkileyen yazarların başında gelen, yazı ve düşünceleri ile salt Fransa'yı değil Avrupa'yı da etkileyen, eşitsizlik üzerine kurulu toplumsal yapının yıkılıp eşitlik üzerinde yeniden inşa edilmesi için uğraşan Jean-Jacques Rousseau'nun (ö. 1778) aynı özveriyi kadın hakları için göstermediği söylenebilir. Zira Emile ya da Çocuk Eğitimi Üzerine (2015, s. 186) adlı yapitında, kadın ve erkeğin toplumsal katılımının eşit ancak aynı tarzda olmadığını; erkeğin kadına göre daha aktif ve güçlü, buna mukabil kadının daha pasif ve zayıf bir katılımcı olduğunu öne sürer. Bununla birlikte kadın-erkek arasındaki ilişkiyi doğal süreçler üzerinden yorumlayan Rousseau, kadının erkeğe haz vermek üzere yaratıldığını savunur. Bu durum eşitlik ve özgürlük söylemlerinin yükseldiği bir ortamda kadın-erkek arasındaki ilişkiyi erkek gücü üzerinden dolayımlayıp kadını erkeğin haz nesnesine çeviren bir köleye dönüştürür (Wollstonecraft, 2012, s. 74). Özgürlüğü ve eşitliği salt yurttaşlık bağlamında ele alan Rousseau, kadının varoluş ereğinin erkeğin sözünü dinlemek ve ona katlanmak olduğunu; bu nedenle kadının eğitiminin erkeğe göre düzenlenmesi gerektiğini savunur. Benzer şekilde Montesquieu (ö. 1755) de kadının erkeğe bağlı olması gerektiğini ancak bunun özel alan -ev- içinde sınırlanması gerektiğini, kamusal alanda siyasal eyleme katılmaları için herhangi bir engel olmadığını belirtir (de Beauvoir, 2011, s. 155). Aydınlanma düşünürlerinin fikirleri kadının geleneksel toplumsal yapıda sahip olduğu kimi hakları sınırlı bir perspektifte genişletiyor gibi görünse de kadın yine aynı ataerkil hegemonik bakışın altında var edilir.

İdealist felsefenin önemli düşünürlerinden Hegel (ö. 1831) de kadının ikincil pozisyonda kalması gerektiğini savunur. Hegel kendinden önce gelen düşünürlerin kavramsallaştırdıkları kadın-erkek arasındaki 
düaliteyi sivil toplum ve aile yapısı içinde açıklamaya çalışır. Buna göre erkek sivil toplumu temsil ederken kadın daha çok aile içinde yer alır. Zira aile, modernlik söylemlerinin baskınlığı altında geleneksel kültürün taşıyıcılığını yapan bir kurumdur. Buna göre bu kurum içinde bireyler araçsallaşmamış ilişkiler kurarak duygular ekseninde yapılandırılır. Üste'nin belirttiği gibi aynı zamanda zihin ile cinsiyet arasında ilişki kuran Hegel, kadın cinsiyetinin bilincini nesnel ölçütlerle işleyen devlet yönetiminden çok öznelliğin baskın olduğu aile kurumu için daha uygun olduğunu belirtir. Bu bağlamda duygusal özelliği ile ön plana çıkan kadın özel alan (aile) içinde aktif iken; erkek rasyonel düşünen bir birey olduğundan kamusal alanda görev alır (Üste, 2015, s. 112-113).

Antik Yunan'dan günümüze kadının erkek karşısında ikincil konumda tutularak oluşturulduğu söylemler haricinde kadın haklarına önem atfeden çalışmalar da mevcuttur. Ortaçağ'da kadın haklarını savunan yazılarıyla öne çıkan Christine de Pisan'ın (ö. 1430), kadının cinsel bir tatmin aracı olduğunu, aşk olgusunu erkeklerin paralarına sahip olmak için kadınların tuzak olarak kullandığını içeren ve kadınların modaya düşkünlüğünü kadın düşmanı bir temaya dönüştüren Roman de la Rose (Gülün Romansı) üzerine girdiği tartışma günümüz feminist düşüncesi için temel oluşturur (Thomasset, 2005, s. 67-68; Hughes, 2005, s. 135; Regnier-Bohler, 2005 s. 416). Konu ile ilgili Pisan'ın The City of Ladies (Kadınlar Şehri) eseri feminist düşüncenin ilk yazılı örneği olarak değerlendirilebilir (Çakır, 2007, s. 416). Pisan, Akıl, Doğruluk ve Adalet erdemlerini temsil eden üç alegorik kadın ile birlikte geçmiş, şimdi ve geleceğin erdemli kadınlarını erkeklerin alçaltıcı sözlerine karşı korumaya çalışır (Riley, 1995, s. 10). Kitabında dünyaya kadın olarak gelmenin talihsizliğini tartışırken kadınların içinde bulundukları toplumsal konumun suçunu ataerkil otoriteye bağlar. Buna göre cinsiyet eşitsizliğini üreten toplumsal roller, kadınların doğal özelliklerinden ${ }^{7}$ dolayı değil ataerkil söylemin ürettiği ideolojik sistem nedeniyle belirlenir (Klapisch-Zuber, 2005, s. 13). Poulain de la Barre (ö. 1723), The Equality of the Two Sexes (İki Cinsiyetin Eşitliği Üstüne) adlı eserinde zihnin cinsiyetsiz olduğu düşüncesini ileri sürer. Descartes'ın kartezyen felsefesindeki zihin-beden ikiliği üzerinden yürüttüğü tartışmada kadın ve erkeklerin aynı becerilere sahip olduklarını ve bu nedenle aynı eğitimi almaları gerektiğini savunur. Aynı şekilde

7 Pisan, kadının doğal özellikleri derken kadının erkekten farklı özelliklerini vurgular. Örneğin, kadının doğurganlık özelliği veya kadının erkekten fiziki bakımdan daha zayıf olması gibi. 
Aydınlanma düşünürlerinden Helvetius da (ö. 1771) kadının erkek karş1sında ikincil planda kalmasının en önemli nedenlerinden aldığı eğitimi sorumlu tutar (de Beauvoir, 2011, s.152, 155). Androsentrik tarihte kadının yok sayılması salt filozof, politikacı ya da bilim insanları tarafından değil edebiyat eserleri üreten yazarlar tarafından da tartışlır. İngiliz edebiyatının önemli yazarlarından Jane Austen (ö. 1817), IV. Henri'den Carl'ın Ölümüne Kadar İngiltere Tarihi adlı eserinde kadınların tarihin nesnesi konumunda olduklarını vurgulayarak tarih yazımında kadının yokluğunu eleştirir. ${ }^{8}$ Görüldüğü üzere kadının bir birey ve toplumsal yaşam içinde bir özne olarak konumlanması hem Aydınlanma öncesinde ve hem de Aydınlanma sonrasında, üzerinde çok durulmasa da mevcuttur.

\section{Dini-Mitolojik Anlatılarda Kadın}

Halikarnas Balıkçısı [Cevat Şakir Kabaağaçlı, ö. 1973), Anadolu Efsaneleri adlı eserinde dünyanın her yerinde kurulan insan topluluklarının ilkin matriarkal olduğunu iddia eder. ${ }^{9}$ Çünkü kadının doğurganlığını doğa ile özdeşleştiren insan, ilk döllenmeden yaklaşık dokuz ay sonra doğum yapan kadını kutsal olarak nitelerken doğum sürecinde erkeğin rolünü yok sayar. Bu bağlamda bilinen ilk insan topluluklarında dişi olana atfedilen yaratıcılık, üreticilik özelliği Tanrıçaların ${ }^{10}$ egemen olduğu bir yapıya işa-

8 Austen kitabında "O tarih kitaplarını okurken o kadar sıkıldım ki, ruh yok. Bakıyorum o kitaplara, deniyor ki '1399 tarihinde IV. Henri sevinçle tacını başına giyer...' büyük ihtimalle kral evlidir. Çünkü onun dört erkek evlada sahip olduğunu biliyoruz; karısınınsa kim olduğunu, hatta başka çocuğu var mı yok mu bilemeyiz, çünkü bunu yazmamışlar, o yüzden ben bunu çok sıkıcı buluyorum, niye kadın yok?" sözleriyle tarihsel metinlerde kadının konumunu sorgular (Çakır, 2011, s. 261).

9 Konu ile ilgili farklı görüşler mevcuttur. Çoğu araştırmacı ilkel toplumlarda anaerkil bir yapının olduğunu iddia etse de kimi araştırmacılar anaerkil yapının hiçbir zaman olmadığını belirtir (Kaya, 2002, s. 49). Örneğin, Kathleen Gough, ailenin kökeni ile ilgili yaptığı bir araştırmada gerçekte anaerkil bir yapının olmadığını öne sürer (197ı, s. 762). Benzer şekilde Anne Barstow, mitlerin ve ilk insanların meydana getirdiği sanat eserlerinin erken dönem toplumlarda kadınların önemli roller üstlendiğini gösterse de kadınların gerçek gücünün aldatıcı olduğu üzerine çeşitli tartışmaların devam ettiğini belirtir (1978, s. 8).

10 Neolitik dönemde özellikle Çatalhöyük'te yapılan arkeolojik kazılarda, yaşam ve yaratıcılığın simgesini işaret eden çeşitli Tanrıça figürlerine ulaşılmıştır (Barstow, 1978, s. 16). Kybele, bu Tanrıça figürleri arasında matriarkal toplumun başını simgeler. Zira Kybele dünyada bitkiler ve hayvanlar için tarımsız verimliliği sağlayan bir Tanrıça'dır (Halikarnas Balıkçısı, 1992, s. 98). Bu bakımdan Kybele, doğadaki dengeyi ve tüm yaşam formlarının belirli bir düzen içinde yaşamalarını sağlayan olumlu bir figürdür. Ataerkil toplum öncesinde anaerkil bir toplumun olduğu tezi Lewis Henry Morgan'ın Kuzey Amerika yerlileri üzerinde yaptığı araştırmanın sonuçları ile kısmen doğru- 
ret eder (Halikarnas Balıkçısı, 1992, s. 21). Ancak yazının icadından sonra günümüze ulaşan belgeler ${ }^{11}$ incelendiğinde ilk uygarlıklardaki toplumsal yapı ve mitlerde ataerkil kültün baskınlığı görülür. Örneğin, Homeros'un eserlerinde kadın genellikle "bir erdem timsali, kocasına sadık, çocuğuna düşün, evinin kadını imajı ile yer alır" (Sınmaz Uzgan, 2018, s. 27). Dişil kutsallığın Hestia ile özdeşleştirildiği Antik Yunan'da kadının kutsal mekânı, aile ocağı olurken toplumsal rolü kendi özel alanıyla sinırlı kalmaya başlar. Zeus ve Hera arasındaki ilişkiye bakıldığında, anaerkil toplumda yaratan, üreten, verimlilik sağlayan Ana Tanrıça'nın ataerkil toplumda evcilleştirildiğine şahit olunur (Berktay, 2000, s. 36). Bu bağlamda ataerkil toplumda Tanrı ve Tanrıça'ların görevlerinin ve aralarında kurulan hiyerarşik ilişkinin toplumsal düzlemde kadın ve erkeğin üstlendiği rolleri yansıttığı söylenebilir.

Kadın ve erkek rollerinin biçimlendirilmesinde din önemli bir yer tutar. Kutsal sözlerle belirlenen bu roller insanüstü bir dil ile insanlara iletilerek insanların o görevleri ifa etmeleri ve bu kurallar bütününden çıkmamaları öğütlenir. Bu durum tektanrılı dinlerin ortaya çıkmasından çok önce Sümer, Yunan vb. mitolojilerinde de belirgin bir şekilde gözlenebilir. ${ }^{12}$ Kadının cinselliği ve bekâretini denetleme mekanizması olarak ortaya çıkan ilk örnekler Eski Ahit'te de bulunmaktadır -evlenen bir kadının gerdek gecesi sonrası kanlı çarşafını sergilemesi örneğinde olduğu gibi (Deut. 22: 16-17). ${ }^{13}$ Kadın-erkek arasında var olan cinsel eşitsizliklerin temeli dini anlatılarda Âdem'in ilk eşi Lilith'e kadar dayanır. Eşit koşullarda yaratılan iki insanın cinsel birleşme sırasında alt ya da üst pozisyonda

lanır. Zira Morgan, yerli kadınların modern toplumsal yaşamdaki kadınlara nazaran daha yüksek statüye sahip olduğunu, dini, siyasal ve ekonomik kurumlarda söz sahibi olduğunu gözlemler. Buradan hareketle Morgan, anaerkil toplumun yerleşik düzene geçildikten sonra değiştiğini savunur (Morgan'dan aktaran Berktay, 2000, s. 38).

11 Konu ile ilgili dünyaca ünlü Sümerolog Samuel Noah Kramer'in Sümer Mitolojisi (2016) ve Tarih Sümer'de Başlar (2014) kitapları Sümerler'de Tanrı ve Tanrıça kavramlarındaki değişimin erkek merkezli bir yapıya dönüştüğünü göstermesi bakımından önemlidir. Bununla birlikte ilk dönem yazılı metinler için bkz. (Jackson, 2012; Aydın, 2017; Anonim, 2016; Homeros, 2016).

12 Muazzez İlmiye Çı̆̆ (2005), Yahudi, Hıristiyan ve Müslüman dinleri ile Sümer dinleri arasındaki benzerlikler olduğunu kutsal kitaplar ve tabletleri karşılaştırarak gösterir. Bu karşılaştırmalardan biri de Âdem'in cennetten kovuluşu ile ilgili olan bölümdür.

13 Bu konuda Lilith ile Âdem arasındaki çatışma örnek gösterilebilir. Tarihteki ilk feminist olarak gösterilen ilk insan Lilith'in cinsel özgürlüğünü korumak için Âdem'in daha üstün olmadığını kabul etmesi ve cennetten kovularak kötülüğün anası olarak betimlenerek dünyada var olan tüm kötülerin sebebi olarak gösterilmesi erkeğin kadını denetim altına alma isteği ve eylemi olarak ilk mitolojilerde ortaya çıkar. 
konumlanmak istemelerinden doğan eşitsizlik, Lilith'in Âdem'in hep üstte olma talebini kabul etmemesi üzerine lanetlenmesi ile sonuçlanır. İlk dönem dini anlatılarda kadının cinsel olarak erkek hegemonyası altında biçimlendirilmesiyle kadın-erkek eşitsizliği tektanrılı dinlerde kökleşerek devam eder. Örneğin, Hıristiyan idealizminde engel olarak konumlanan tutku, arzu kavramları ilerleyen yıllarda çileci düşüncede bekâreti koruma ile sonuçlanır. Bu bağlamda kadınların hissizleşmiş bir nesneye dönüşerek Hıristiyan teolojide arzularını çarmıha geren, bedenlerine karşı yabancılaşan cinsellikleri kontrol altına alınır (Castelli, 1986, s. 73).

Çığ'ın belirttiği gibi eski uygarlıklarda var olan dini mitler ile tektanrılı dinler arasında benzerlikler kurulabilir (2005, s. 15). Ancak burada dikkat edilmesi gereken nokta dini söylemlerde kadının nasıl temsil edildiğidir. Yaratılış ve cennetten kovulma hikâyeleri incelendiğinde dinler arası benzerlikler kurmak mümkündür. Hikâyeler temelde Yılan/ Şeytan'ın Havva'yı baştan çıkarıp yasak meyveyi önce Havva'nın yemesi ve sonrasında Âdem'in yemesine neden olması üzerine kuruludur. Havva'nın arzusuna/nefsine yenik düşüp kendini ve Âdem'i yoldan çıkarması ve bunun üzerine cezalandırılmaları söz konusudur. Hikâyenin bu şekilde yapılandırılması Eski Ahit ve Yeni Ahit'in ataerkil söylem üzerine inşa edildiğine bir örnektir. ${ }^{14}$ Ancak şu da unutulmamalıdır ki, ataerkilliğin kurumsallaştırılması tektanrılı dinlerle başlamamıştır. Mitolojik söylenlerde de kadın, erkek karşısında negatif kodlarla inşa edilir. Örneğin, Yunan mitolojisinde, Prometheus'un tanrılardan çaldığı ateşi (bilgiyi) insanlara ulaştırması üzerine Zeus'un intikamı kadın üzerinden gerçekleşir. Tanrıların Armağanı anlamına gelen Pandora, efsaneye göre yaratılan ilk kadındır. Bütün kötülükleri içinde barındıran bir kutu ile kesinlikle açmaması öğütlenerek dünyaya gönderilir ancak arzu ve merak duygusuna

14 Kuran'da Cennet'ten Kovulma, Yahudi ve Hıristiyan geleneğinden farklı olarak Havva'nın nefsine yenik düşmesi sonucu Âdem'i baştan çıkarması ile sonuçlanmaz. Kuran'da Âdem ile eşinin cennetten yeryüzüne gönderilmesinde her ikisi de suçludur. Ancak dini anlatılarda ataerkil söylem sadece tek bir örnek üzerinden geliştirilmez. Hatta bu örnekte de kadının ikincil pozisyonda resmedildiği anlaşılabilir. Zira Bakara Suresinin 35. ayetinde Tanrı sözlerini doğrudan Âdem'e yöneltir, Âdem'in eşi ikinci plandadır: "Dedik ki: Ey Âdem! Sen ve eşin cennete yerleşin. Orada dilediğiniz gibi bol bol yiyin ama şu ağaca yaklaşmayın, yoksa zalimlerden olursunuz" (Kuran 2:35, Diyanet İşleri Başkanlığı meali); "Ve Âdem'e şöyle buyurmuştuk: Ey Âdem, sen ve eşin cennete yerleşin ve orada dilediğiniz yerde, bol bol yiyin. Ama şu ağaca yaklaşmayın, yoksa zulme sapanlardan olursunuz" (Kuran 2:35, Yaşar Nuri Öztürk meali); "Ve dedik ki: Ey Âdem, sen ve eşin cennete yerleşin, ikiniz de orada dilediğiniz yerde bol bol yiyin, ancak şu ağaca yaklaşmayıı ki, haddini aşan zalimlerden olmayasınız" (Kuran 2:35, Elmalılı Hamdi Yazır meali). 
yenik düşen Pandora kutuyu açar ve insanlığın başına tüm belaları sarar (Lachs, 1974, s. 341). Görüldüğü üzere dini ve mitolojik metinlerde kadının zayıf, günahkâr olduğu düşüncesi ilk insanlar üzerinden kurulup yıllar boyu toplumsal düzende uygulanır. Bu bağlamda Akıl'ı temsil eden erkeğin Arzu'suna yenik düşen kadını denetim altında tutması gerekir.

Tektanrılı dinlerde tanrının sözleri kutsal kitap aracılığıyla insanlığa iletilir. Kitabın kutsallığının Tanrı tarafından belirlendiği için sorgulanması ve eleştirilmesi mümkün değildir. Bu bağlamda kutsal metinlerde kullanılan dilin özelliği $1^{15}$ ve kapsayıcılığı önem kazanır. Eski Ahit'te kadının yaratılışı şu şekilde betimlenir: "Ve Rab Âdem'den aldığı kaburga kemiğinden bir kadın yaptı ve onu Âdem'e getirdi. Ve Âdem dedi: Şimdi bu benim kemiklerimden kemik ve etimden ettir" (Gen. 2:23). Günümüzde hâlâ etkili olan ilk kutsal metinlerden Eski Ahit'te kadın erkeğin bir parçası olarak tanımlanır. Erkek, bedeninin bir parçası -kaburga kemiği- ile var olmuş kadın karşısında üstün, diğer bir anlamda yaratıcı konuma geçer. ${ }^{16}$

15 Çalışmanın genelinde kutsal metinden yapılan alıntılar literal yorum türüne göre incelenmiştir. Çalışmanın başında da belirtildiği üzere çalışmanın ana amacı kutsal metinlerde var olan eril dili ortaya çıkarmaktır. Kutsal metinlerde bulunan derin anlamı bulup çıkarmaktan ziyade kadın ve erkeğin arasında nasıl bir ilişki kurulduğunu göstermektir. Örneğin, kutsal kitapların çoğu erkek figürler (özellikle üç büyük kitapta mesajların doğrudan Musa, İsa ve Muhammed'e iletilmesi) üzerinden bir anlatı kurulması gibi. Ancak şunu da belirtmek gerekir ki kutsal metinlerin literal, ahlakçı, tarihsel, hermenötik gibi birçok farklı yorum türü mevcuttur. Bu yorum türleri, kutsal metinlere farklı yollarla ulaşıp derindeki anlamı bulmaya çalışırlar. Örneğin, hermenötik yorumlama biçimlerinden alegorik yöntem, kutsal metinlerdeki sözlerin birincil anlamlarının ötesinde felsefi anlamların olduğuna inanır (Tarakçı, 2010, s. 207). Benzer şekilde hermenötik öğretinin önemli temsilcilerinden İskenderiye okulunda kutsal kitapları inceleyen üç farklı yöntem gelişir: literal, sembolik ve psikolojik. Bu yöntemlerden literal yönteme göre kutsal metinler mecazi yorumlara kaçmadan açık anlamı ile yorumlanır. Zira kutsal metinler üzerine ancak olanaklı ise yorum yapılır (Doru, 2011, s. 169). Sembolik yöntem hakikatin "duyusal ve akılsal dünyanın sınırlarını aşan bir" yapıda olduğu varsayımı üzerinden ancak sembolik yorumlanabileceğini ileri sürer. Ayrıca kutsal metinlerde kullanılan dilin anlamlandırılması da farklılıklar arz eder. Buna göre metinler, tek anlamlı, çok anlamll, analojik ve indirgemeci dil olarak kategorilenir (Tokat, 2009, s. 83-89). Görüldüğü üzere kutsal metinlerin çok farklı dili anlama ve yorumlama biçimleri mevcuttur. Bu bağlamda çalışmada gerçekleştirilen yorumlama biçimi diğer yorumlama türlerini yadsımamaktadır. Ancak çalışma, kutsal metin ve insan arasında ilk kurulan anlam inşasının literal boyutta olduğu varsayımından hareketle literal yöntemi kullanmaktadır. Ayrıntılı bilgi için bkz. (Erş, 2018; Paden, 2008).

16 Burada dikkat edilmesi gereken diğer bir nokta ise, kadının neden kaburga kemiğinden yaratıldığı ile ilgilidir. Genesis Rabbah'da kadın mağrur olmasın diye Âdem'in kafatasından, istekli olmasın diye gözünden, meraklı olmasın diye kulağından, çok konuşmasın diye ağzından, kıskanç olmasın diye kalbinden yaratılmamıştır. İnsan vü- 
$\mathrm{Bu}$ durum yaratıcının -veya güç sahibi olanın- kimliğini dilsel zeminde erkeğe doğru çevirir. Bununla birlikte kutsal kitapta Tanrıya atfedilen Baba, Lord, Efendi ${ }^{17}$ gibi isimler eril niteliğe sahiptir. Aynı zamanda kutsal mekân kullanımında da erkek baskınlığı yıllar içinde giderek artar. Yahudi kadınların sinagoglarda ayrı yere oturmaları ve Hıristiyan kadınların kilisede konuşma yapmalarına izin verilmemesi bu durumlara örnek gösterilebilir. Hıristiyanlığın kurucularından Pavlus'un bu konudaki görüşleri önemlidir: "Kiliselerde kadınlar sükût etsinler; çünkü onlara söylemek için izin yoktur; ancak şeriatın da dediği gibi, tabi olsunlar. Ve eğer bir şey söylemek isterlerse, evde kendi kocalarına sorsunlar; çünkü kadına kilisede söylemek ayıptır" (aktaran Berktay, 2000, s. 96). Kadının her ne sebeple olursa olsun kutsal mekândan koparılması din ile erkek arasında kurulacak olan bağın giderek güçlenmesine ve erkeğin dini söylem altında kadına karşı yaptırımlarında haklı olacağına işaret eder.

Tevrat'ta kadın-erkek ilişkilerinde erkek egemenliğinin varlığını destekleyecek birçok söylem mevcuttur. Cennetten kovulma mitinde Havva'nın cezalandırılmasına atfen doğum ile ilgili şu sözler yer alır: "Kadına şöyle dedi: Çocuk doğururken sana çok acı çektireceğim. Ağrı çekerek doğum yapacaksın. Kocana istek duyacaksın, seni o yönetecek" (Gen. 3:16). Aynı zamanda evlilik kurumu ile ilgili söylemlerin tümü erkek egemen bakışla inşa edilmiştir. Erkeğin birden fazla eşinin olması ancak kadının bu haktan mahrum edilmesi, boşanmanın erkeğe tanınan bir ayrıcalık olması kutsal kitabın eril dile sahip olduğunun göstergeleridir.

Yahudi anlatıya karşın Hıristiyan öğretide kadın, kutsal metinde bahsi geçen kutsallık mertebesine erişen bir figür olur. Meryem'in, azizelerin ve İsa çarmıha gerilirken toplanan kadınların varlığı Hıristiyanlıkta kadını tinsel bağlamda yüceltir. Ancak İncil'de kadın ve erkek arasında kurulan güç ilişkisine bakıldığında kadın her daim erkeğin altında yer alır. Örneğin Korintlilerin 11. bölümünde şu ifadeler yer alır: "Her erkeğin başı Mesih, kadının başı erkek, Mesih'in başı da Tanrı'dır... Erkek başını örtmemeli, o, Tanrı'nın benzeri ve yüceliğidir. Kadın da erkeğin yüceliğidir. Çünkü erkek kadından değil, kadın erkekten yaratıldı. Erkek kadın için

cudunun gizli bir bölgesinden yaratılması kadının mütevazı, ağırbaşlı olması içindir (Ünal, 2017, s. 106).

17 Tevrat, Eski Ahit, Yeni Ahit metinlerine bakıldığında eril dile ait benzerlikler göze çarpar. Tanrı'nın sıfatları arasında güç, iktidar belirtici sözcükler kullanılır. Aynı zamanda özellikle Tanrı için İngilizce'de erkek egemenliğin daha belirgin olduğu görülür. Tanrı için cinsiyet belirten zamirlerden erkekler için kullanılan " $\mathrm{He}$ " kullanılır. 
değil, kadın erkek için yaratıldı." Görüldüğü üzere kadının varlık sebebi erkektir. Kadının ontolojik olarak kutsal bir metinde erkeğe mahkûm edilmesi geleneksel toplumlarda kadınların Tanrı'nın sözüne uyarak verilen emirleri içselleştirmelerini ve bunu kültürel boyuta aktarmalarını sağlar. Dinin kültürelleşmesi ise gelecek nesillerin rolleri ve davranış kalıplarını sorgulamadan benimsenmesine yol açar. Hıristiyanlıkta erkeğin baskınlığının diğer bir nedeni de erkeğe yüklenen kutsallık payesidir. Zira üçlü teslis Hıristiyan doktrininde Tanrı Baba, Oğul ve Kutsal Ruh'tan oluşan üç unsuru ifade eder. Burada önemli olan nokta Baba'dır. "Baba ile oğul arasinda kurulan bağlantı Hıristiyan söyleminin temelini oluşturur. Modern perspektiften bakıldığında mecaz ifadeler olarak görülse de gerçekte Baba erkek ebeveyndir" (Hick, 1993, s. 43). Ancak teolojik söylemde Tanrı imgesi dişi ve erkek cinsiyetlerinin ötesinde olması gereken bir varlıktır.

\section{Teolojiye Feminist Bir Bakış}

Bütün dinlerin temeline inildiğinde kutsal, olmazsa olmaz bir kavram olarak ortaya çıkar. Eliade'a göre kutsallık kavramıyla örülü dini simgesel sistem, tektanrılı dinlerden önce de var olan bir durumdur (1990, s. 83). İnsan sembol üreten bir varllk olduğundan tarihin ilk döneminden günümüze doğayı anlamlandırmaya çalıştığı için doğa olaylarına çeşitli anlamlar yükleyip kutsiyet atfetmiştir. Kaynağı tabiatüstü bir unsura dayanan bu kutsiyet toplumsal yaşamda karşılığını çeşitli sembol ve simgelerle bulur. Ancak bu simge ve sembollerin insanlara ulaştırılmaları kutsalın yeryüzündeki temsilcilerinin ortaya çıkmasını sağlar. İnsanın aşkın güç karşısında kendini aciz bir varlık olarak kabullenmesi kutsal dinde temsil edilen kişilere saygı duyulmasını zorunlu kılar (Otto, 1917, s. 20-23).

Hıristiyan geleneğinde kutsallık İsa ile başlar. Tanrı'nın oğlu sıfatına sahip İsa'nın yeryüzünde bütün insanlığı kurtarmak için acı çekerek kurban edilmesi onun kutsiyetini belirten en önemli unsurlardandır. $\mathrm{H}_{1}-$ ristiyan geleneğinde, İsa Mesih'in yeryüzüne tekrar gelip insanlığı kurtaracağı şeklinde bir inanç vardır. Zira İncil'de İsa'nın tüm insanlık için kendisini nasıl feda ettiği birçok bölümde anlatılır. ${ }^{18}$ İsa'nın kendini feda etmesi Hıristiyan öğretinin temel dinamiklerinden asli günah kavramı

18 "Kutsal Yazılar uyarınca Mesih günahlarımıza karşılık öldü" (1. Korintliler 15, 3); "Tanrı'yı biz sevmiş değildik, ama O bizi sevdi ve Oğlu'nu günahlarımızı bağışlatan kurban olarak dünyaya gönderdi" (1. Yuhanna 4, 10); "Bu sizin uğrunuza feda edilen bedenimdir" (Luka 22, 19); "[...] canını birçokları için fidye olarak vermeye geldi" (Matta 20, 28.). 
ile ilişkilendirilir. Pavlus'un mektuplarında açıklanan asli günah kavramı, yeryüzüne Âdem aracılığıyla ulaşmıştır. Bütün insanlığı bu günahtan kurtaracak olan ise Tanrı'nın suçsuz oğludur. Görüldüğü üzere dini anlatıda bütün insanlığı kurtaran kişi olarak erkeğin gösterilmesi Hıristiyan öğretide erkeğin kutsal olarak tanımlanmasına neden olur. Bu bağlamda kutsal ve erkeklik birbiri ile iç içe geçen iki kavrama dönüşür. İsa Mesih'in kendisini tüm insanlık adına kurban ederek günahlarına kefareti İncil'in birçok bölümünde insanlığın nihai olarak aklandığını belirten ifadelerle desteklenir. ${ }^{19}$ İnsanlığın kurtuluşunu simgeleyen İsa Mesih, dünyada gerçek ve ebedi mutluluğa ulaşmaya vesile olur. İlk insanlar yüzünden Tanrı ile ihtilafa düşen insan, İsa Mesih vasitasıyla ilişkisini düzeltir.

Erkeğe yüklenen kutsallık ve kurtarıcılık vasıfları kadın-erkek arasinda kurulan ilişkinin eşitsizlik üzerinde temelleneceğini gösterir. Bu bağlamda öncelikle eşitlikçi cinsiyet anlayışını tanımlayabilmek için temel teolojik kavramların yeniden yapılandırılması gerekir (Haddad \& Esposito, 2002, s. 66-68). Bu bakımdan toplumsal cinsiyet değerler dizisine karşı eleştirel yaklaşımla mücadele eden feminist teoloji yol gösterici olabilir. Konu ile ilgili özellikle 20. yüzyılın ikinci yarısından sonra giderek artan çalışmalar genellikle teolojinin feminist bakış açısıyla yeniden düzenlenmesi gerektiği ile ilgilidir. Buna göre, Hıristiyan din öğretisinin erkek egemen karakterini ortaya çıkararak cinsiyetler arası eşitsizliği ortadan kaldırmak için alternatif bakış açıları geliştirilmeye çalışılır. Mary Daly (1985 ve 1986), Elizabeth Cady Stanton (2006), Elizabeth Grosz (1990), Johanna Martina Wood (2013), Rosemary Radford Ruether (1993) gibi düşünürlerin çalışmaları ataerkil söylemin cinsiyet eşitsizliği yaratan bakış açısını yıkıcı bir okumaya tabi tutar. ${ }^{20}$ Feminist teolojik yak-

19 "Onun ölümü günaha karşıllk ilk ve son ölüm olmuştur" (Romalılar 6, 10); "O, öbür başkahinler gibi her gün önce kendi günahları, sonra da halkın günahları için kurbanlar sunmak zorunda değildir. Çünkü kendini sunmakla bunu ilk ve son kez yaptı" (İbraniler 7, 27); "Sonsuz kurtuluşu sağlayarak kendi kanıyla kutsal yere ilk ve son kez girdi" (İbraniler 9, 12); "Tanrı'nın bu isteği uyarınca, İsa Mesih'in bedeninin ilk ve son kez sunulmasıyla kutsal kılındık" (İbraniler 10, 10).

${ }^{20} \mathrm{Bu}$ çalışmalara ek olarak liberal, kültürel ve radikal feminist hareketler de ataerkil söylemi farklı bakış açıları üzerinden yıkıcı okumaya tabi tutarak kadının kamusal ve özel alandaki konumunu yeniden inşa etmeye çalışır. Özellikle dinin kültürün yaşam alanına sızarak toplumsal yaşamda kadın-erkek ilişkilerini ve rollerini belirlediğinin farkına varan kültürel feministler, 19. yüzyılda kutsal varlıkların (Tanrı, peygamber, Mesih gibi) erkek olarak betimlenmesine ve kutsal metinlerin ataerkil bir dile sahip olmasına karşı çıkar (aktaran Çaylı Rahte, 2018, s. 28). Bunun üzerine yeni bir toplum modeli inşa etmeye çalışan kültürel feministler, barışseverlik, işbirliği, farklılıkların şiddetsiz birlikteliği ve kamusal alanın uyumlu düzenlenmesi gibi özelliklere sahip 
laşım özellikle dogmatik teolojik anlayışın epistemolojik ve metodolojik süreçlerini sorgular.

Dini anlatıların feminist okumaya tabi tutulması metindeki eril dili mercek altına alır. Çünkü erkek egemen bakış hiyerarşik bir düşünce sistemi içerisinde hareket ettiğinden iki farklı cinsi tek bir kategori -erillikiçinde temsil eder. Grosz bu durumu dişil olanı, eril olanın içindeki temsil olarak yorumlar (1990, s. 150). Bu temsil kadının erkeğin ötekisi olarak algılanması ve erkeğe boyun eğmesiyle sonuçlanır.

Linguistik çerçevede değerlendirildiğinde eril terimlerle isimlendirilen Tanrı, dilsel sınırlar çerçevesinde cinsiyetsiz olarak yeniden tanımlanmalıdır. Zira Tanrı'nın sadece eril insanlık tarafından temsil edilebileceği düşüncesi Hıristiyan öğretide Mesih'in eril olmasını zorunlu kılar. Wood, bu konu hakkında, Tanrı'nın eril olarak temsil edilmesinin erkekler için sorun teşkil etmezken kadınların Tanrı'dan soyutlanmalarına neden olabileceğini belirtir (2013, s. 174). Bu bağlamda kendini Tanrı'dan soyutlayan kadın yıllarca erkek rol modellerin dayatmasına maruz kalır. Daly, modern teologların zihinlerinde var olan Tanrı kavramlarının sorunlu ve hatta zararlı olduğunu ileri sürer ve her şeye gücü yeten, kadir-i mutlak gibi insanüstü kavramlarla bağlantılı olarak ortaya çıktığını düşünür. Tanrı'nın değişmezliğinin yarattığı problem, baskıcı durumların var olmasına izin veren bir Tanrı imgesini yansıtır. Hıristiyan öğretide Tanrı'nın değişmezliği onu statik bir nesne konumuna sokarak onunla ilgili kullanılacak kavramların sinırlandırılmasına neden olur (1985, s. 19, 83). Bu durum dilsel pratikte Tanrı'ya atfedilen erkek imgesinin sinılandırılmış kavramlar kümesinden oluşturulduğunu gösterir. Özellikle Tanrı'nın eril zamirlerle isimlendirildiği bir dünyada her şeye gücü yetenin sadece erkek olduğu fikri aşılanır ve bu düşünce insanlar tarafından za-

toplum modeli için anaerkil ütopyadan beslenirler (Donovan, 1997, s. 70). Margaret Fuller'in Woman in the Nineteenth Century (19. Yüzyılda Kadın) adlı eseri ile anaerkil toplum ütopyasının temelleri atılır. Fuller, toplumda kültürün kadınlaştırılması ile dönüşümün mümkün olabileceğini yazar (Çaylı Rahte, 2018, s. 32). 1915 yllında Charlotte Perkins Gilman, anaerkil ütopya türünün ilk örneklerinden Herland'de (Kadınlar Ülkesi) Amazon'un dağlık bölgelerinde erkeklerin olmadığı, sınıfsız kadınlar toplumunu anlatır (Öğüt, 2012, s. 32). 1960'dan sonra feminist hareket içinde ütopya yeni mücadele araçlarından biri olur ve toplumsal cinsiyet eşitsizliklerini yok etmek için yeni ütopyalar ve karşı ütopyalar ortaya çıkar. Örneğin, 1970'li yıllarda kabile yaşamından esinlenerek yazılan, anaerkil toplumların anlatıldığı Marge Piercy'in Women on the Edge of Time (1976), Marion Zimmer Bradley'in The Ruins of Isis (1978), Monique Wittig'in Les Guerillas (1969) ve Jayge Jarr'ın Levithan's Deep (1979) adlı eserleri önemli feminist ütopyalardandır (aktaran Gültekin, 2006, s. 20). 
man içinde içselleştirilir. ${ }^{21}$ Böylece Daly'nin ifadesiyle "eğer Tanrı erkekse, o zaman erkek Tanrı'dır" (1985, s. 19) mantıksal sonucu ortaya çıkar.

Feminist teolojik yaklaşıma göre, Tanrı imgesi zihinlere dini metinler ve edebiyat gibi yazınsal ürünlerle eril figür olarak yerleştirilir. Özellikle kilisenin egemen olduğu dönemde pek çok sanatçı tarafından Tanrı'nın erkek olarak resmedilmesi insanların zihinlerinde Tanrı'nın erkek olarak imgelenmesine neden olur (Daly, 1985, s. 13). Bu nedenle kad1nın erkek karşısında özgürleşmesinin temeli dinsel anlatılarda kullanılan erkek egemen bakışın yok edilmesine bağlıdır. Hıristiyan teolojisinin temel dayanağı olan varoluş mitinde eksik insan olarak betimlenen kadının özne olmadığını vurgulayan Butler, dişil olanı "eksiğin imlenmesi" olarak yorumlar. Burada imleyen kadın-erkek olanı belirli kurallarla farklılaştıran dilsel kodlardır (2016, s. 81). Bu dilsel kodlar ise simgesel düzeyde eril bakışla tesis edilir. Konu ile ilgili Ruether'in Sexism and God-Language eseri, erkeğe yüklenen ilahi ve kutsallık vasıflarını kadınlar için de oluşturmaya çalışır. Antik Yunan mitolojisinden beslenen ancak Tanrı-Tanrıça figürünü yadsıyan Hıristiyan tektanrıcı anlayışı eril düşüncenin kökleşmesinin başat nedenlerindendir. Dişil olanın yadsınmasının Hıristiyan üçlü teslisinde Kutsal Ruh'a yapılacak olan dişil betimleme ile çözümlenebileceğini düşünen Ruether, eril hâkimiyet düşüncesinden bu şekilde uzaklaşılabileceğini savunur (aktaran Topcan, 2010, s. 70).

Geçmişten günümüze belirli kültürel kodlar dâhilinde aktarılan çeşitli kurallar dizgesine sahip öğretilerden oluşan teolojik yapının tamamı erkekler tarafından oluşturulmuştur. Cinsiyetler arası eşitsizliğe neden olan bu durum, tek bir cinsin yapılandırdığı sistemsel düzenlemenin tüm insanllk için var olduğu düşüncesini savunur. İşte feminist teologlar bu düşüncenin evrenselliğini sorgular. Böylece feminist teoloji, geleneksel kurallar içindeki kadını, nesne konumundan kurtarıp eşitlikçi bir din anlayışı içinde onu yeni teolojik düşüncenin öznesi yapmaya uğraşır (King, 1989, s. 163). Aynı zamanda dinde var olan ikili karşıtlıklar zemininde temellenen düşünce sisteminin değişmesi hatta reddedilmesi gerektiği savunulur. Teolojinin toplumsal cinsiyeti üreten bir mekanizma gö-

${ }^{21}$ Konu ile ilgili Elizabeth Cady Stanton Woman's Bible (Kadının İncili, 2006) adlı kitabında Tanrı'yı referans gösteren zamirlerin İngilizce'de "He" (erkek için O) olarak kullanıldığını belirtir. İncil'in 27. ayetinde Tanrı'nın eril ve dişil imajının temsil edildiğini söyleyen Stanton, kadına sonradan imaj kazandırmanın nasıl mümkün olabildiğini sorgular ve bir dilin yetersizliğinin birçok yanlış anlaşılmaya neden olabileceğini ileri sürer. 
revi görmesinden dolayı ataerkil yapının tamamen yadsınması gerekir ki kadının öteki olarak konumlanmayacağı bir toplumsal sistemde yeni bir bilinç inşası mümkün olsun (Daly, 1985, s. 29). Kadının kendi varlığının bilincine varması ve dini tahakkümün ortadan kalkıp erkek kutsallığının yerine insanın cinsiyet kavramından sıyrılıp tüm bir varlık olarak konumlanması toplumsal sistemde özgürleşimi sağlar. Zira eril teolojik paradigmanın tahakkümü içinde düşünce ve algılama sistemlerinin eril düzenin belirlediği şematik yapı içinde içselleştirilmesi ataerkil sistemin meşruiyetini sağlayan temel dinamiktir. Özgürleşimin sağlanabilmesi, bu sistemsel yapı içinde eleştirel bilincin tesisi ile mümkündür.

Bununla birlikte feminist teoloji, cinsiyet temelli ayrımlara da karşı çıkar. Günümüz modern toplumsal yaşamında kadınların Mesih'i temsil etme yeteneğini reddetmeleri, İsa ile aynı cinsiyeti paylaşmadıklarından kaynaklanmaktadır. Dikkat edilmesi gereken dini ya da mitolojik anlatılarda tarihsel ayrıntıların içinde İsa ya da diğer dini figürlerin erkekliklerine verilen ayrıcalıktır. Bu bağlamda Hıristiyan geleneğinin ataerkil önyargılarıyla özellikle İsa'nın erkekliğine yapılan vurgular üzerinden mücadele edilmesi gerekir. Bu mücadele alanını popüler kültürün ve gündelik yaşamın bütününü kapsayacak şekilde genişleterek kültürel ürünlerde var olan androsentrik bakışı görünür kılmak, insanların zihninde katılaşmış düşünce kalıplarını yıkarak tekrar inşa etmek ve inşa edilen yeni metin ile gelenekselleşmiş toplumsal kabulü yok etmek feminist teoloji için önem arz eder.

\section{Kadın Mesih Neden Olmasın? ${ }^{22}$}

Mesih figürü, sinema sanatının doğuşundan bugüne, özellikle bilimkurgu türünde kullanılan popüler bir temadır. Ancak temelde İsa ve Mesih temalarının birbirinden farklı olduğunu kavramak gerekir. Zira İsa filmleri, İsa'nın yaşamı ve ölümüne yaşadığı toplumsal düzlem içerisinde odaklanırken; Mesih filmleri, Mesih'in kişiliğine, mesajına ve insanlığ kurtarma görevine odaklanır. Mesih figürleri filmlerde çeşitli eylemler üzerinden tanımlanır: Çarmıha gerilmek, su üstünde yürümek, kendini aşkın sevgisi uğruna kurban edip insanı ya da insanlığı kurtarmak. Nite-

22 Modern sanatta Mesih'in kadın olarak temsil edildiği birçok örnek mevcuttur. Bunlar resim, heykel, edebiyat gibi sanatın birçok alanında üretilmiştir: Resim ve heykelde, Arthur Boyd (1979-80) Crucifixion, Shoalhaven; James M. Murphy (1984) Christine on the Cross; Margaret Argyll (1993) Bosnian Christa; edebiyatta, Kittredge Cherry (2007) Art That Dares: Gay Jesus, Woman Christ örnek olarak gösterilebilir (Slee, 2012, s. 73). 
kim önemli bir tema olarak kefareti kullanan bir filmin, kurtarıcı kahraman figürüyle bağlantılı olarak bu sembolleri kullanması gerekir (Kozlovic, 2004, s. 1). Teolojik tarihte kurtarıcının erkek olarak düşünülmesine karşın sinema sanatının olanakları kullanılarak Mesih'in kadın olabileceği yönündeki düşünce, kadın ile erkek arasında var olan eşitsizlikleri dini yönden gidermek için bir adım sayılabilir. Bu nedenle çalışma feminist teolojik bakışla filmdeki kadın Mesih figürüne odaklanır.

Kendi istekleri yerine yaşadığı çevrenin kabul ettiklerine ve tamamen bağnaz bir toplumun isteklerine göre yaşayan ve bu istekleri hiç sorgulamamış olan Bess, İskoçya'nın kuzeybatısında katı Kalvinist inancın hüküm sürdüğü küçük bir kasabada bir petrol işçisiyle evlenir. Taşra ahlakının ağırlığının hissedildiği bu küçük toplulukta yabancılarla evlenilmesi çok hoş karşılanmaz. Düğünü takip eden günlerin sonrasında Jan, işi gereği rafineriye gider ve felçli olarak geri döner. Bunu duyan Bess yıkılır; ancak kocasını iyileştirmek için elinden geleni yapar. Jan, Bess'ten kendisine bir iyilik yapmasını ister. Jan'a göre ölüm, cinselliği unutmasıdır ve unutmaması için Bess'ten tanımadığı erkeklerle cinsel ilişkiye girip kendisine anlatmasını ister. Bess bir gün denizdeki teknelerden birine yine ilişkiye girmek için gider. Ancak öldüresiye dayak yer, hastaneye kaldırılır ve sonrasında ölür. Buna karşın filmin sonunda Jan sağlığına kavuşur ve Bess'in cesedini arkadaşları ile birlikte çalıp denize bırakır ve çanlar gökyüzünde çalmaya başlar.

Lars von Trier, filmleri için konu seçerken aşırı, uç fikirleri denemeyi sevdiğini belirtir. Dalgaları Aşmak filminde bu uç fikirler, din, cinsellik, transandantal sevgi ve iyilik kavramlarının harmonisini oluşturur. Filmin çıkış noktası iyilik kavramında temellenir. Altın Kalp (Gold Heart) çocuk kitabındaki kız çocuğuna dayanan filmin ana karakteri, Altın Kalp kitabındaki kız çocuğu gibi kurban rolünün aşırı uç temsilini içerir (von Trier, 2007, s. 230). Bununla birlikte din ve aşk kavramları ise filmin özünü oluşturur. Bu öz cinsellik ve transandantal sevginin bağlayıcılığı ile birlikte çok katmanlı bir yapıya dönüşür. Filmde yer alan dini temalar göz önüne alındığında film, dini bir film olarak değerlendirilebilir. Zira filmin dramatik yapısında kutsal, kurban ve kurtarıcı (Mesih) gibi birçok sorunsal din zemini üzerinden sorgulanir.

Dalgaları Aşmak filminde var olan din, cinsellik ve iktidar kavramlarının birbirleri ile doğrudan veya dolaylı kurdukları ilişkiler, filmde kadın ve erkek temsillerinin eşitlik, iyilik, geleneksellik, gerçeklik zeminlerinde yorumlanmasına olanak sağlar. Ancak din, filmde kurucu temel öge ola- 
rak yerini alır ve hikâyeyi iki farklı bağlama oturtur. ${ }^{23}$ Bunlardan ilki katı Hıristiyan öğretileri ile belirlenmiş kuralları yaşayan bir toplulukta bir kadının aşkı için kendini feda etmesini tolere etmeyen ve dinin sertliğini ortaya koyan bir yaklaşım; diğeri ise transandantal sevgisinin peşinden sürüklenen kadının, inancının içsel-dışsal sonuçlarını görmezden gelerek aşkını kurtarmak için kendini kurban etmesi ve bunun sonucunda mucizevi bir şekilde hem aşkını kurtarması hem de topluluğun önyargısinı kırmasıdır.

Reel dünyanın koşulları çerçevesinde kardeşinin vefatından sonra akli dengesini yitiren Bess, filmde zihinsel olarak tutarsız bir görüntü çizer. Filmin birçok yerinde Bess'in, duygusal taşkınlık yaşadığı zamanlarda sesli (bağırarak, çığlık atarak) ya da fiziksel olarak (filmin ilk sahnesinde Jan'ı gelinliği ile beklerken ona vurması, Jan rafineriye giderken demir parçasını sağa sola vurması vb.) şiddetli dışavurumları görülür. $\mathrm{Bu}$, Bess'in içinde taşıdığı sıkıntıları, buhranları boşaltması için bir yoldur. Yukarıda bahsedildiği üzere film iki farklı bağlama oturtulduğundan filmde iki farklı Bess vardır: Birincisi filmin ilk sahnesinde sorguya çekilirken görüntülenen gülümseyen, etrafına neşe saçan, pozitif Bess; diğeri histeri krizlerine tutulan, etrafına ve kendine zarar verebilen şiddete meyilli olan, negatif Bess. Filmin hikâye akışında ilkin dindar bir kadın olarak betimlenen Bess'in filmin başındaki cenaze sahnesinde kadınların cenazeye katılmaması gibi taşranın koyduğu kuralları sorgulamadığı, doğrudan içselleştirdiği görülür. Zira Bess, Tanrı ile içsel iletişime geçip Tanrı'nın yönlendirici söylemleri doğrultusunda hareket eden biridir. Buna karşın Jan ile tuvalette yaşadığı cinsel birleşme sırasındaki eylem ve söylemleri, arzuları doğrultusunda hareket eden bir kadını işaret eder. $^{24}$

Filmde kişileşme süreci25 içinde Bess, Tanrı ile diyaloğunun yön-

${ }^{23}$ Film, Hıristiyan dini motifleri kullandığı ve İsa Mesih'in insani ve tanrısal özelliklerini yücelttiği için Hıristiyan öğretinin iyi taraflarını gösterir. Aynı zamanda yozlaşmış ve gelenekselleşmiş Hıristiyan ahlakının da bir eleştirisini yapar.

24

Bess'in evlilik sonrası hemen cinsel birleşme isteği Havva ve Pandora gibi arzularına yenik düşen bir figüre dönüşmesine neden olur. Dindar kasabanın ahlaki ve dini kurallarıyla yaşayan Bess, cinsel eylem pratiği sorunlu bir kadındır. Bu bağlamda filmde cinsellik hem Bess'i hem de Jan'ı kurtarmak için kullanılan bir araçtır. Bess'in kilise ve kasabanın tahakkümünden kurtulup evlendiği insanla cinsel ilişkiye girip özgürleşmesini sağlarken, Jan kendi varlığını cinsellik ile yeniden inşa eder.

${ }^{25}$ Kişileşme süreci kavramı, genellikle Jungcu yaklaşımda kullanılan, bireyin bilinç ve bilinçdışının bütünleştirilmesi süreci olarak tanımlanır. Kişileşme sürecinde insan kendi benliğini felsefi, mistik ve ruhsal açıdan tümler. Aynı kavramı Sartre, bireyin bir 
lendirici etkisi göz önüne alındığında, histeri krizlerine kapılan, sağlıklı düşünemeyen bir insan iken bir insanın hayatını kurtarmak için kendini kurban eden kutsal bir varlığa dönüşür. ${ }^{26}$ Hatta bu dönüşüm süreci sonunda yaptığı davranış Tanrı katında ödüllendirilir ve filmin sonunda, çanı olmayan kasabanın gökyüzünde çanlar çalmaya başlar.

Dalgaları Aşmak filmi, Bess'in kişileşme sürecini daha net anlayabilmek ve hikâyenin gelişim aşamalarını ayrımlayabilmek için yönetmen tarafından sekiz epizoda ayrılmıştır: Bess'in Evliliği, Jan ile Yaşamak, Yalnız Yaşamak, Jan'ın Hastalığı, Şüphe, İnanç, Bess'in Kurban Edilişi ve Cenaze. Filmin hikâye akışında bölümlenen bu sekiz epizot kutsal, kurban ve kurtarıcı motiflerinin örüldüğü ve iç içe geçtiği alanları ayrımlar. Örneğin, Jan'ın Hastalığı bölümünden sonra Jan ve Tanrı'nın Bess ile diyalogları Bess'i ataerkil sistemin kurbanı olma yolunda hazırlar. Buna karşın erkeğin kutsallığına atfedilen Tanrı ile iletişime sadece erkeklerin geçebileceği düşüncesi, filmdeki Bess karakteri ile sorgulanır. Bu bakımdan Bess'in kendi karakterini inşa sürecinde kadın ve kutsal kavramlarının birlikteliğini tesis etmek için Tanrı ile yaptığı konuşmalar önemlidir. Zira Bess, evlilik ile başlayan ve ölüm ile sonuçlanan filmsel yaşamında delilikten kutsallığa Tanrı'nın kendisine verdiği mesajlar yoluyla ulaşır. ${ }^{27}$

Filmin ana temalarından biri olan transandantal iyilik, Bess'in kutsal bir figüre dönüşmesini sağlayan önemli itici güçlerden biridir. Kilisede Tanrı ile yaptığı iyi biri olma ile ilgili konuşmada Bess, Tanrı tarafından ilkin bencillikle suçlanır. Hatta Tanrı, Bess'in kendi duygularının herkesten önce geldiğini ve bu nedenle Jan'a duyduğu aşkı göremediğini söyler ve kendisinden iyi bir kız olacağına dair söz ister. Ardından Bess,

"süreçten geçerek kendine özgü bir bireye, kişiliğe" dönüşmesi olarak tanımlar (Biemel, 1984, s. 199). Bu çalışmada kavram Jungcu ve Sartrecı tanımlamanın sentezi biçiminde kullanılır. Buna göre kavram, bireyin beden-ruh ve yaşam felsefesi açısından kendini tümlediği ve diğerlerinden özgün bir kişiliğe dönüştüğü bir süreci niteler.

${ }^{26}$ Filmde kendini kurban etme eylemi İsa Mesih'in asli günah için diğer bir deyişle tüm insanlığın günahlarına kefareti için kendini kurban etmesi ile benzerdir. Aynı zamanda Yahudilik ve İslamiyet'te geçen, bir insanı kurtaran bütün insanlığı kurtarmış olur düşüncesinden hareketle Bess, sadece Jan'ın hayatını değil tüm kasaba halkını dini tahakkümden kurtarır.

27 Bess'in Tanrı ile yaptığı konuşmalar tektanrılı dinlerde peygamberlere gelen vahyin bir benzerini göstermektedir. Mircea Eliade'ya göre peygamberler vahiyleri inzivaya çekildikleri bir yerde vecd halinde alırlar. İnsan-Tanrı arasındaki iletişim reel dünyada diğer insanlar tarafından suçlayıcı bir bakışla reddedilir (2003, s. 80-82). Filmde Bess'in Jan'ın hastalığı ile ilgili olumlu söylemleri Bess'in psikolojik sorunlu kimliğine atfen reddedilir ve kutsallığı yok sayılır. 
Tanrı'ya verdiği sözü tutarak iyi bir insan olma yolunda ilk adımı atar ve annesinden davranışları için özür diler. İyilik temas ${ }^{28}$ film boyunca birçok yerde tekrarlanır. İyilik, iyi olma kavramları İncil'e göre tanrısal vasıflara gönderme yapar: "Bana neden iyi diyorsun, iyi olan tek biri var, $\mathrm{O}$ da Tanrı'dır" (Markos, 10:17-18). Görüldüğü üzere İsa'ya göre tek iyi Tanrı'dır, ancak İsa, kutsal, masum, doğru olarak nitelendiğinden Mesih'in Tanrı ile iyilik vasfını paylaştığı söylenebilir. Bu bağlamda İsa da Bess de iki farklı doğaya (Tanrısal-Beşeri) sahiptir.

Bess'in kendisinin ilahi güçlerinin (kutsal) olduğuna dair inancı doktor ile yaptığı konuşmada ortaya çıkar:

Bess: Platformda gerçekleşen şey benim hatam yüzünden oldu.

Dr. Richardson: Nasil yani?

Bess: Tanrı'ya onu eve göndermesi için dua ettim.

Böylece Bess, Jan'ın kazası ve Tanrı'ya duası ile bir bağıntı kurar. Ancak bu bağıntı, birden fazla olay ile tekrarlanması halinde mantıklı bir düzleme oturur. Hatta ilkin Jan'ın isteğini geri çeviren Bess, hastaneye gittiğinde Jan'ın fenalaştığını görür ve kiliseye gidip Tanrı'ya yalvarır:

Bess: Ölmesine izin verme.

Tanrı: Neden ölmesine izin vermeyeyim?

Bess: Onu seviyorum.

Tanr: Sürekli bunu söylüyorsun ama ben bunu göremiyorum.

Bess: Yapabileceğim bir şey yok. Hiçbir şey.

Tanrı: Bana onu sevdiğini kanıtla ben de yaşamasına izin vereyim.

Film boyunca tekrarlanan bu süreç (dua etme-iyileşme arasındaki ilişki) filmin hikâye akışında Bess'in kutsallığına olan inancını pekiştirir ancak aşkını kurtarabilmesi için Tanrı tarafından sınanması gerekir. Jan'ın kasabaya felçli olarak dönmesi ile birlikte Bess için inisiyasyon süreci başlar. Bess, ameliyat sonrası Jan'ın ölmeyeceğini ancak felç kalacağını ve çok ciddi acılar çektiğini öğrenir. Hıristiyan gelenekte yazdığı gibi ilk günahın cezasını çekmek için dünyaya gelen insanlığı Jan simgeler-

${ }^{28}$ Filmde Bess ile sosyal çevre arasında kurulan zıtlık, Nietzsche'nin iyi ve kötü kavramları ile yakın ilişki içindedir. Ahlakın Soy Kütüğü (2011) adlı eserinde Hıristiyan ahlak sisteminin dünyaya dayatıldığını ve bu sistemin yapay olduğunu ileri süren Nietzsche, sevginin ahlaki bir içeriğinin olmadığını ve hatta iyi ve kötünün ötesine geçtiğini söyler. Bu bağlamda sevgi-aşk kavramları ahlaki bir içeriğe sahip değildir. Hatta yaşamın temel duygularından olduğu için ahlaki sistem içinde var olan her şeyden daha saf ve iyidir. Bu bağlamda film, reel toplumsal düzlemde var olan ahlaki gerçeklik ile bu gerçekliğin ötesinde transandantal sevginin kural tanımazlığı arasındaki gerilimi yansitır. 
ken çektiği acılar asli günahın yansımasıdır. Bu acılardan kurtulabilmesi Hıristiyan öğretide yer alan Mesih'in günahlarının kefaretini ödemesi ile mümkün olacaktır:

Tanrı: Jan'ın eve dönmesini sen istedin [...] Seni sınamak zorundaydım. Jan'a olan aşkın sınanmalıydı.

Filmde Bess'in sınavı, geleneksel anlamda sevdiği insanın bakımını üstlenmek değil, cinsellik üzerine temellenen aşırı bir durumla simgelenir. Jan'ın yaşarken ölmemesi için Bess'in bir sevgili bulması ve onunla yaşadığı cinsel deneyimleri kendisine anlatması gerekir. Zira Jan için aşk, her şeye gücü yetendir. Eğer ölürse sebebi aşkın kendisini hayata bağlayamamasıdır. Jan'ın isteği, temsil ettiği insanlığın soyunun devamı için gerekli olan cinsel birleşmenin simgesel düzeyde hayatta kalabilmesinin koşuludur. Bu radikal isteğin Dodo ve Jan arasında geçen konuşmada "Senin için her şeyi yapar, Jan" (von Trier, 1996) cümlesinden sonra geldiği gözden kaçmamalıdır. Aynı şekilde Dodo'nun Bess'e "Her şey sana bağl. Başka kimsesi yok. Ona yaşama gücü verebilirsin. Bunu bir doktordan daha iyi yaparsın." (von Trier, 1996) şeklindeki sözleri Bess'in eylemlerini belirleyen unsurlardan biridir. ${ }^{29}$ Zira reel düzlemde filmin rasyonel tarafını betimleyen Dodo tarafından kendisine ağır bir görev yüklenen Bess'e, irrasyonel düzlemde de Tanrı tarafından aynı görev verilir. Bu bağlamda Bess, birbirine karşıt iki farklı düzlemde kurtarıcı olarak betimlenir.

Jan'ın isteği doğrultusunda aşkı uğruna bedenine çile çektirmek için kimi eylemlerde bulunan Bess'in kişileşme sürecinde çileci davranışları yine Tanrı ile diyaloğunda belirginleşir:

Bess: Ben cehenneme mi gideceğim?

Tanrı: Kimi kurtarmak istiyorsun? Kendini mi yoksa Jan'ı mı?

Bedeni üzerinden cinsel şiddet yoluyla çile çeken Bess, filmde insanötesi bir varlık olarak konumlandırılır. Cinsel şiddet ile hastalığın iyileşmesi arasında kurulan ilişki filmin diğer ana dayanak noktalarındandır. Bess'in tanımadığı bir adama mastürbasyon yapması ve bunu Jan'a anlatması ile Doktor Richardson'un "duaların kabul oldu, onu solunum cihazından çıkarttık" müjdesi arasında kurulan metafiziksel bağ, Bess'in aşkının iyileştirici gücüne (kutsallığına) olan inancını arttırır: "Ölmeyeceğini biliyorum. Sana söz veriyorum."

${ }^{29}$ Konu ile ilgili von Trier \& Shiloh, Bess'in iyiliğinin ve fedakârlığının diğer karakterler tarafından sömürüldüğünü, hatta sadizm ve vahşet isteklerini tetiklediğini öne sürer. Bunu ise Dodo'nun Jan'a yaptığı bu konuşmaya bağlar (2005, s. 87). 
Bess'in Jan'ın iyileşme süreci ile maruz kaldığı cinsel şiddet arasında kurduğu bu irrasyonel bağlantı, filmin altıncı epizodu İnanç'ta iyice pekişir. Aynı durum, Bess'in tanımadığı bir erkekle cinsel ilişkiye girmesi ve Jan'ın ameliyatının başarısı ile kurulan ilişkide ve Doktor Richardson ile yaptığı konuşmada görülür:

Dr. Richardson: Peki, senin yeteneğin ne Bess?

Bess: İnanabilirim.

Bess'in inanç düzleminde kendi kişiliğini geliştirmesi bir kurtarıcı olarak çektiği çilenin seviyesi ile ölçülür. Pavlus'un öğretileri doğrultusunda bedenin çileci zihniyetle disiplin altına alınması -kadının disipline edilmesi- cinselliğin disipline edilmesini gerektirir. Alyda Faber "Redeeming Sexual Violence? A Feminist Reading of Breaking the Waves" adlı makalesinde Bess'in cinsel şiddete maruz kalmasını feminist kuram çerçevesinde değerlendirip Bess'in transandantal iyiliğini mazoşist bir yoksunluk olarak erkek egemenliğini değerli kılan ve kurtarıcı yorumuyla cinsel şiddete yatırım yapan şüpheli bir yapı olarak temsil ettiğini ileri sürer (Faber, 2003). Aynı şekilde Plate \& Jasper'ın vurguladığı gibi Irena Makarushka, "Transgressing Goodness in Breaking the Waves" adlı çalışmasında Bess'in ne trajik ne de kutsal bir kahraman olarak göründüğünü belirtir. Diğer birçok kadın gibi, reel dünyada var olan geleneksel patriarkal sistem içinde Bess, iki farklı kültürün temel yansıması, bakire ve fahişe olarak inşa edilir (Plate \& Jasper, 1999, s. 61). Eril bakışla yorumlanan kadın Mesih figürü, ruh ve beden karşıtlığını tersine çevirmeye çalışırken kadının kurtarıcı (Mesih) olabilmesini cinsel şiddete maruz kalmasına bağlayarak yalnızca Mesihin cinsiyetinin kadın olarak yorumlanmasına neden olur. Diğer taraftan kutsal bir figür olarak kadın, acıyı dahi erkek tahakkümünde çekmesine mecbur bırakılıp kişileşme sürecinde erkeğin sadist isteklerine cevap vermeye çalışan zavallı bir figüre dönüşür.

Antik dönemde Platon'un Akıl ile erkek ruhu, modern çağın başlangıcında Descartes'ın Ruh ile eril zihni ilişkilendirmesi filmde kadın karakterler tarafından temsil edilir. Tarih boyunca bedene karşı üstün tutulan Akıl ve Ruh, Dodo ve Bess üzerinden aktarılır. Verdiği öğütlerle Bess'i kurtamaya çalışan, yol gösteren ve akıl veren Dodo mantıksal çıkarsamalarla ve pozitif bilimlerin ışığında Jan'ın yaşadığı komplikasyonları ve tedavi sürecini Bess'e anlatmaya çalışır. Bununla birlikte Descartes'ın belirttiği bedenin kirleticiliği geleneğini transandantal sevgisine kefaret olarak kullanan Bess için bedeni, Ruh'u kurtarmak için bir araçtır. Akıl ve Ruh arasında kurulan ilişki Dodo ve Bess'in diyaloglarında ortaya çıkar: 
Bess: Onun hayatını kurtaran kişi benim. Tekrar kurtarabilirim. Dodo: Bess, neden bahsediyorsun?

Bess: Ona aşk hakkında hikâyeler anlattım. Aşkın Jan'ı kurtarabileceğini görüyorsun. Aşkı unutmamalı.

Dodo: [...] senin üzerinde çok fazla gücü olmasına izin verme. Hastalığın merhameti yoktur.

Dodo ile Bess arasında kurulan rasyonel - irrasyonel bağıntı Jan'ın Bess üzerinde kurduğu tahakküm ile açığa çıkar. Pek çok düşünür Tanrı inancının, sevgisinin ve dinin irrasyonel olduğunu iddia eder (Dawkins, 2007, s. 312-315; Plantinga, 1981, s. 41). Zira kutsala duyulan sevgi insan tarafindan kontrol edilemez; bireyin yaşadığı toplumsal çevre nedeniyle kanıksadığı ve içselleştirdiği bir durumsal çerçeve içinde anlam kazanır. Bu bağlamda, Bess'in aşkını kurtarmak için transandantal sevgisini rasyonel olmayan bir boyutta, diğer bir deyişle yaşadığı çevreye anormal (normal olmayan) bir şekilde yaşaması ve buna göre eylemlerde bulunması, İsa'nın insanlık için çektiği çile ile aynı düzlemdedir. Ruh-beden karşıtlığını kadın ve erkek cinsiyetleri üzerinden kuran Hıristiyan öğretisini tersine inşa eden filmde Bess'in bedeninin yok edilişi ile İsa'nın çarmıha gerilerek acı içinde bütün günahlara kefareti arasında ilişki kurulabilir. Çünkü İsa'nın eylemleri ve söylemleri bulunduğu toplumsal çevre içinde normal karşılanmayan, yıkıcı nitelikler taşımaktaydı. Filmde bu görev Bess'in hem aşkını kurtarma hem de çevresel önyargıyı kırma düzleminde ortaya çıkar. Bu nedenle Dodo, Bess'in yaptığı eylemleri reel toplumsal bağlamda değerlendirdiği için tepki gösterir:

Dodo: Onun sapık fantezilerini beslemek için başka erkeklerle mi yatiyorsun?

Bess: İyileşti.

Dodo: Hayır, iyileşmedi! Hastalığı bu şekilde ilerliyor Bess. Bazen iyi olur, bazen kötü. Yaptığın şeylerle ona bir faydan dokunmuyor [...]

Bess: O benim kocam ve Tanrı onu onurlandırmamı söyledi.

Dodo: $\mathrm{Bu}$ onurlandırmaksa eğer o halde bir sorun olmalı.

Bess'in inancının taşra ahlakı ve kilise öğretisinin ötesine geçişi gemiden kurtulduktan sonra kiliseye gittiğinde yazılmış kelimeleri ve konulmuş kuralları koşulsuz bir aşkla sevmenin nasıl mümkün olabileceğini düşünmesi ile başlar. Kiliseye uygunsuz bir kıyafet ile giren Bess, Pavlus'un -kadınlar kilisede sükût etsinler- buyruğuna karşı gelerek gelenekselleşmiş Hıristiyan öğretisine karşı yıkıcı cümleler kurar: "Ne söylediğinizi anlamıyorum. Bir kelimeyi nasıl sevebilirsiniz? Aşkı kelimelere sığdıramazsınız. Bir kelimeye âşık olamazsınız. Başka bir insanı sevebi- 
lirsiniz. Mükemmel olan budur". Mükemmellik ile insan sevgisi arasında kurulan bu ilişki filmde cinsellik ile farklı bir boyutta ele alınır. Bess, dini tahakküm altında baskıladığı cinselliğini Jan ile aşarak özgürleşir ve aile, kilise gibi kurumları karşısına alır. Transandantal sevgisi ve inancının yıkıcı özelliklerini yok sayan Arnfridur Gudmundsdottir'e göre Bess, İsa'nın yaşadığı dönemin norm ve değerlerini yıkan ve kendi öğretisini yerleştiren bir yaklaşıma sahip değildir. Aksine Bess, taşranın katı kuralları ve erkek egemen baskının altında ezilen bir fail, bir kurbandır (2002, s. 35). Bu yaklaşım doğru olmakla birlikte eksik bir yan içermektedir. Daha önce belirtildiği üzere Bess, beşeri ve tanrısal özellikler gösteren iki farklı doğaya sahiptir. Bu bağlamda Bess, iki farklı düzlemde yorumlanmalıdır. Beşeri açıdan değerlendirildiğinde Bess'in maruz kaldığı acılar ile Mary Magdalena arasında ilişki kurulabilir. Ancak karşılıksız ve koşulsuz sevgi ile inanç perspektifinden bakıldığında kurtarıcı (Mesih) vasfını yüklenebileceğini gösterir. Zira filmin sonuna doğru Dodo'nun Jan'ın mucizevi kurtuluşuna tanık olması akli dengesinin yerinde olmadığını düşündüğü Bess'e hak vermesini sağlar ve kuralların nedenselliğini sorgulamadığı kasabadaki erkek otoriteye karşı çıkar. Diğer bir önemli gösterge ise Bess'in, gemicilerin elinden kurtulduktan sonra çocuklar tarafından taşlanarak İsa'nın Golgota'ya çıkarken çektiği çileye benzer bir durumu yaşamasıdır. Bu bağlamda Bess'in film boyunca iki farklı kutsal kimliği temsil ettiği söylenebilir. İnanç, sevgi, kutsal, kurban, kurtarıcı gibi kavramlar açısından Mary Magdalane ve İsa'ya benzediği yönler bulunur. $O$ halde kişileşme süreci içinde Bess, başlangıçta Mary Magdalane ile geleneksel bağlarını koruyup finale doğru yıkıcı özellikleriyle Mesih'e doğru evrilerek kendini kurban eder.

Filmin sonuna doğru Bess'in kutsallığının toplumsal çevre tarafından kabulü Doktor Richardson'un mahkeme kayıtlarına, çektiği acıların kaynağına bağlanarak verilir. Rasyonel düşüncenin karşısında yer alan bu maddi-olmayan ifadeler Bess'in bir kurban olarak kendisini insanlara kanıtladığının ispatıdır. Aynı şekilde finale doğru Bess inanç bayrağını Dodo'ya teslim eder. Bess'in cenazesinde dindeki erkek baskınlığına "hiçbirinizin Bess'i cehenneme göndermeye hakkı yok" (von Trier, 1996) şeklinde karşı çıkışı, Bess'in başlattığı erkek egemen tahakkümün yıkıcılığının devamlılığını gösterir.

Dalgaları Aşmak filmi kutsal, kurban ve kurtarıcı kavramlarını kadın karakter üzerinden sorgulayan, bunu yaparken dinde var olan kutsal kişileri kadın perspektifinden yorumlayan görsel bir metindir. Ancak 
Bess, peygamberlik vasıflarını yüklenmiş dönemin normlarına karşı gelen bir figürü betimlerken erkek bir yönetmenin gözünden Bourdieu'nun (2015) belirttiği eril tahakkümün ${ }^{30}$ sınırları çerçevesinde yapılandırılmıştır. Bu sınırlar özellikle cinsel şiddet üzerinden belirginleşerek Descartes'ta olumsuz olarak betimlenen bedenin acı ile kendi kutsallığını kurarak ve bu kutsallığın eril Tanrı'nın buyrukları ve erkeğin (Jan) istekleri doğrultusunda tesis edilerek çizilir. Hıristiyan geleneğine bir eleştiri niteliğinde yıkıcı özellikler taşıyan film, aynı zamanda eril bakışın gözetiminde kadın karakteri erkek egemenliği altında ezilen ve şiddete maruz kalan bir nesne olarak gösterir.

\section{Sonuç}

Feminist teologların İncil'i hermenötik okuması Mesih figürünün erkek egemenliğini kırmak için çeşitli kanallar açar. Dalgaları Aşmak filmi bu kanallar üzerinden çözümlendiğinde kadın mesih figürü ile dolaylı ve dolaysız iletişim kurmak mümkün olmaktadır. Hıristiyan öğretide kullanılan çeşitli kavram ve eylemleri kadın karakteri üzerinden yorumlanmasını sağlayan film, inanç ve iyilik temelinde Hıristiyan teolojisine göre kurban imajı sunar. Sembolik düzlemde kurtarıcı figürünü temsil eden kadın karakter (Bess) hem Mesih'dir hem değildir. İki boyutlu ele alındığında filmin akış aşamasında, çektiği çilenin boyutuna göre gelişen, olgunlaşan Bess, Mary Magdalane temsilinden Mesih'e doğru kayar. Platon ve Descartes düşüncesinde Akıl ve Beden'i bir arada temsil eden Bess, transandantal sevgisi ile taşra ahlakının ötesine geçer ve aşkının faili ve kurbanı olur. Filmin natüralist boyutunda çılgın, akli dengesi yerinde olmayan bir fahişe gibi resmedilirken, spiritüel boyutunda göğe yükselen, aşkı için kendini kurban eden, tanrısal iyiliğe sahip bir karakter olarak tanımlanır.

30 Pierre Bourdieu, eril tahakküm kavramı ile verili toplumsal yaşamda içselleştirilen tüm olgu ve düşünce stratejilerine nüfuz eden tahakküm biçiminden söz eder. Buna göre var olan eril iktidar söylemlerine karşı geliştirilen eleştiriler, karşı-söylemler eril tahakkümün sınırlarını çizdiği belirli bir çerçeveden geliştirilir. Bu nedenle herhangi bir yıkıcı özelliği içinde taşımaz. Bourdieu, toplumsal düzeni, eril tahakkümü sürekli yeniden üreten sembolik bir makineye benzetir: "Toplumsal düzen, amacı, üzerine temellendiği eril tahakkümü tasdik etmek olan devasa bir sembolik makine gibi işler: o, işgücünün cinsiyetçi bölünümüdür (faaliyetlerin, yerleri, zamanları ve araçları ile iki cinsin her birine çok katı bir şekilde pay edilmesiyle); o, mekânın yapısıdır (erkeklere ayrılmış olan toplanma ve pazar yerleriyle kadınlara ayrılmış ev arasındaki ayrımla, veya, ev içinde, eril kısım olan salon ile dişil kısım olan ahır, su ve bitkiler arasındaki ayrımla); o, zamanın yapısıdır, tarımsal gün veya yıl, ya da yaşam döngüsüdür (eril olan kırılma anları ve dişil olan uzun gebelik dönemleriyle)" (2015, s. 23). 
Sinemada Mesih figürünün metaforik, alegorik temsili için birçok yol mevcuttur. Dalgaları Aşmak, ilk bakışta dindar bir kasabada geçen bir aşk hikâyesi gibi görünürken derin düzlemde incelendiğinde Hıristiyan teoloji ile birçok paralelliğini kurmak mümkün olmaktadır. Sinema sanatının olanakları toplumun gelenekselleşmiş, kalıplaşmış dini mitlerini yeniden okuyarak postmodern din anlatılarını yeniden yazmayı sağlar. Yönetmen filmde aşkın iyilik kavramını, Bess'e cinsel şiddet yoluyla çile çektirip olgunlaşmasını sağlayarak ve mucize yaratarak bunu somutlaştırır. Ancak erkek egemen bakışla yapılandırılan kadın Mesih figürünün kurtarıcı kimliğini cinsel şiddet üzerinden tesis etmesi, filmdeki feminist eleştirinin sadece cinsiyet boyutunda kalmasina neden olur. Filmde yer alan eril söylemler ve feminist eleştirel yaklaşım dâhilinde Dalgaları Aşmak filmi, post-modern bir yaklaşımla din-sinema ilişkisini yeniden kuran yapısökümcü bir film olarak tanımlanabilir. Ancak filmde kadın karakterin kutsallığının eril tahakküm sınırları çerçevesinde yapılandırılması Lars von Trier'nin din eleştirisini dahi eril bakış açısıyla yaptığını gösterir.

Kadınların mücadele tarihinde sanatın bir araç olarak kullanılarak görsel-düşünsel bağlamda desteklenmesi ataerkil eşitsizliğin yıkılması için bir olanak sunar. Sinema sanatının bu mücadele tarihindeki rolü, modern toplumsal yaşamda hâlâ devam eden eşit olmayan kadın-erkek ilişkisini dini figürleri eril tahakkümden sıyırıp kavramları tersine çevirip yeniden kurarak yeni düşünce kanalları açmayı sağlaması olacaktır.

\section{Kaynakça}

Alphabet of Ben Sira 78: Lilith. (T.Y.). Jewish Women's Archive. https://jwa.org/media/alphabet-of-ben-sira-78-lilith (Erişim Tarihi: ol Eylül 2018).

Alhojailan, M. I. (2012). Thematic Analysis: A Critical Review Of Its Process and Evaluation. West East Journal of Social Sciences, 1(1), 8-21. https://fac.ksu.edu.sa/sites/default/files/ta_thematic_analysis_dr_mohammed_alhojailan.pdf (Erişim Tarihi: ol Eylül 2018).

Anonim (2016). Bâbil Yaratılış Destanı -Enuma Eliş (Çev. S. F. Adalı \& A.T. Görgü). İstanbul: İş Bankası Kültür.

Aristotle. (2013). A Treatise on Government [Özgün eser 1912'de basilmiştır]. https://www.gutenberg.org/files/6762/6762-h/6762-h. htm (Erişim Tarihi: ol Eylül 2018). 
Aydın, N. (2017). Hammurabi Yasaları. İstanbul: Alfa.

Barstow, A. (1978). The Uses of Archeology for Women's History: James Mellaart's Work on the Neolithic Goddess at Çatal Hüyük. Feminist Studies, 4(3). 7-18. doi: 10.2307/3177535

Berktay, F. (2003). Tarihin Cinsiyeti. İstanbul: Metis.

Berktay, F. (2000). Tektanrılı Dinler Karşısında Kadın. İstanbul: Metis.

Biemel, W. (1984). Sartre (Çev. V. Atayman). İstanbul: Alan.

Blundell, S. (1995). Woman in Ancient Greece. Massachusetts: Harvard University Press.

Bourdieu, P. (2015). Eril Tahakküm (Çev. B. Yılmaz). İstanbul: Bağlam.

Boyatzis, R. E. (1998). Transforming Qualitative Information: Thematic Analysis and Code Development. CA: Sage.

Brinkman, M. E. (2013). Jesus Incognito: The Hidden Christ in Western Art since 1960. New York: Rodopi.

Butler, J. (2016). Cinsiyet Belast: Feminizm ve Kimliğin Altüst Edilmesi (Çev. B. Ertür). İstanbul: Metis.

Castelli, E. (1986). Virginity and Its Meaning for Women's Sexuality in Early Christianity. Journal of Feminist Studies in Religion, 2(1), 6188. https://www.jstor.org/stable/25002030 (Erişim Tarihi: 20 Eylül 2018).

Çakır, S. (2007). Feminizm: Ataerkil İktidarın Eleştirisi. H. B. Öz (Ed.), 19. Yüzyıldan 20. Yüzүıla Modern Siyasal İdeolojiler (s. 413-475). İstanbul: İstanbul Bilgi Üniversitesi.

Çakır S. (2011). Kadınların Tarih Yazımı. E. Özdemir \& S. Bayraktar (Ed.), İstanbul - Amargi Feminizm Tartışmaları (s. 253-276). İstanbul: Amargi.

Çaylı Rahte, E . (2018). The Brand New Testament'ta Alternatif Bir Dünya Kurgusu: Babalık Krizi ve Anaerkil Ütopya. sinecine: Sinema Araştırmaları Dergisi, 9(2), 7-37.

Çığ, M. İ. (2005). Kuran İncil ve Tevrat'ın Sümer'deki Kökeni. İstanbul: Kaynak.

Daly, M. (1985). Beyond God the Father. Toward a Philosophy of Women's Liberation. Boston: Beacon.

Daly, M. (1986). The Church and the Second Sex. Boston: Beacon.

Dawkins, R. (2007). Der Gotteswahn. Berlin: Ullstein. 
De Beauvoir, S. (2011). The Second Sex (Çev. C. Borde \& S. Malovany-Chevallier). New York: Vintage.

Donovan, J. (1997). Feminist Teori (Çev. A. Bora, M. Ağduk Gevrek \& F. Sayılan). İstanbul: İletişim.

Doru, N. (2011). Felsefe Tarihinde Süryanilerin Yeri ve Önemi. M. N. Doru (Ed.), Geçmişten Günümüze İdil (s. 163-176). Şırnak: Şırnak Üniversitesi.

Duby, G. \& Perrot, M. (Ed). (2005). Kadınların Tarihi (Çev. A. Fethi). İstanbul: Türkiye İş Bankası.

Eliade, M. (1990). Dinin Anlamı ve Sosyal Fonksiyonu (Çev. M. A. Aydın) Ankara: Kültür Bakanlığı.

Eliade, M. (2003). Dinsel İnançlar ve Düşünceler Tarihi Cilt 3 (Çev. A. Berktay). İstanbul: Kabalcı.

Engels, F. (1979). Ailenin, Özel Mülkiyetin ve Devletin Kökeni (Çev. K. Somer). Ankara: Sol. (Özgün eser 1884 tarihlidir).

Erş, İ. (2018). Kutsalın Yorumu: Kutsal Metinler Üzerine Hermenötik Denemeler. İstanbul: Siyah Kitap.

Faber, A. (2003). Redeeming Sexual Violence? A Feminist Reading of Breaking the Waves, Literature \& Theology, 17(1), 59-75. https:// www.jstor.org/stable/23925778 (Erişim Tarihi: O1 Eylül 2018).

Gleichauf, I. (2007). Kadın Filozoflar Tarihi (Çev. L. Uslu). Ankara: ODTÜ Geliştirme Vakfı.

Gough, K. (1971). The Origin of the Family. Journal of Marriage and Family, 33(4), 760-771. doi: 10.2307/349449

Gudmundsdottir, A. (2002). Female Christ-figures in Films: A Feminist Critical Analysis of Breaking the Waves and Dead Man Walking. Studia Theologica, 56, 27-43. doi: 10.1080/003933802760115426

Grosz, E. (1990). Contemporary Theories of Power and Subjectivity. S. Gunew (Ed.), Feminist Knowledge: Critique and Construct (59-121). Londra: Routledge.

Gültekin, F. E. (2006). Feminist Utopias As Represented in Joanna Russ' Works: The Female Man and The Two of Them. (Yayımlanmamış Yüksek Lisans Tezi). Dokuz Eylül Üniversitesi Sosyal Bilimler Enstitüsü, İzmir. 
Haddad, Y. Y. \& Esposito, J. L. (Ed.). (2002). Daughters of Abraham:Feminist Thought in Judaism, Christianity, and Islam, Gainnesville: Florida University.

Halikarnas Balıkçısı (1992). Anadolu Efsaneleri. Ankara: Bilgi.

Hartocollis, A. \& Alcindor, Y. (2017, 21 Ocak). Women's March Highlights as Huge Crowds Protest Trump: 'We're Not Going Away'. The New York Times. https://www.nytimes.com/2017/01/21/us/womens-march.html (Erişim Tarihi: 03 Ekim 2018).

Hatch, E. (1897). The Influence of Greek Ideas and Usages upon the Christian Church. Londra: Williams \& Norgate.

Hick, J. (1993). The Metaphor of God Incarnete. Westminister: John Knox.

Homeros. (2016). İlyada (Çev. A. Erhat \& A. Kadir). İstanbul: İş Bankası Kültür.

Hughes, D. O. (2005). Kadın Modasını Düzenleme (Çev. A. Fethi). C. Klapisch-Zuber (Ed.), Kadınların Tarihi II Ortaçağ'ın Sessizliği (s. 134155). İstanbul: Türkiye İş Bankası Kültür.

Jackson, D. P. (2012). Gılgamış Destanı (Çev. A. Antmen). Ankara: Arkadaş.

Jamieson, A., Slawson, N. \& Khomami, N. (2017, 22 Ocak). Women's March events take place in Washington and around the world as it happened. The Guardian. https://www.theguardian.com/lifeandstyle/live/2017/jan/21/womens-march-on-washington-and-other-anti-trump-protests-around-the-world-live-coverage (Erişim Tarihi: 23 Eylül 2018).

Kaya, M. (2002). Türk Halk Anlatılarında Kadın. Toplumbilim, 15, 4954.

King, U. (1989). Woman and Spirituality. Londra: Macmillian.

Klapisch-Zuber, C. (2005). Kadınları Dahil Etmek (Çev. A. Fethi). C. Klapisch-Zuber (Ed.), Kadınların Tarihi II Ortaçağ'ın Sessizliği (s. 1120). İstanbul: Türkiye İş Bankası Kültür.

Kozlovic, A. K. (2004). The Structural Characteristics of the Cinematic Christ-figure, The Journal of Religion and Popular Culture, 8(1), 5-5. doi: 10.3138/jrpc.8.1.005

Kramer, S. N. (2016). Sümer Mitolojisi (Çev. H. Koyukan). İstanbul: Kabalc1. 
Kramer, S. N. (2014). Tarih Sümer'de Başlar (Çev. H. Koyukan). İstanbul: Kabalc1.

Lachs, S. T. (1974). The Pandora-Eve Motif in Rabbanic Literature. Harvard Theological Review, 67, 341-345. doi: 10.1017/ Sool7816000016850

Lyold, G. (1996). Erkek Akıl: Batı Felsefesinde Erkek ve Kadın (Çev. M. Özcan). İstanbul: Ayrıntı.

Mardin, Ş. (1990). Din ve İdeoloji. İstanbul: İletişim.

Marx, Engels \& Lenin. (1992). Kadın ve Aile (Çev. A. Gelen). Ankara: Sol.

Millett, K. (2011). Cinsel Politika (Çev. S. Selvi). İstanbul: Payel.

Nietzsche, F. (2011). Ahlakın Soykütüğü: Bir Polemik (Çev. Z. Alangoya). İstanbul: Kabalc1.

Nye, A. (1988). Feminist Theory and The Philosophies of Man. Londra: Routledge.

Otto, R. (1917). The Idea of the Holy: An Inquiry into the Non-Rational Factor in the Idea of the Divine and Its Relation to the Rational (Çev. J. W. Harvey). Oxford: Oxford University.

Öğüt, H. (2012). Lezbiyen Aşkın Feminist Eleştiri İçin Kazanım ve İmkanları-I, Feminist Politika, 16, 31-33.

Paden, W.E. (2008). Kutsalın Yorumu (Çev. A. Kurt). Bursa: Sentez.

Plantinga, A. (1981). Is Belief in God Properly Basic? Noûs, 15 (1), 4151.

Plate, B. \& Jasper, D. (Ed.). (1999). Imag(in)ing Otherness: Filmic Visions of Living Together. Atlanta: Scholars.

Radford Ruether, R. (1993). Sexism and God Talk: Toward a Feminist Theology. Boston: Beacon.

Reinhartz, A. (2009). Jesus and Christ-figures. J. Lyden (Ed.), The Routledge Companion to Religion and Film (s. 420-440). Londra: Routledge.

Regnier-Bohler, D. (2005). Edebi ve Mistik Sesler (Çev. A. Fethi). C. Klapisch-Zuber (Ed.), Kadınların Tarihi II Ortaçağ'ın Sessizliği (s. 407458). İstanbul: Türkiye İş Bankası Kültür.

Riley, D. (1995). Am I That Name? Feminism and the category of Women in History. Minneapolis: University of Minnesota. 
Rousseau, J. J. (2015). Emile ya da Çocuk Eğitimi Üzerine (Çev. M. Baştürk). İstanbul: Kilit.

Sezer, M. (2017, 29 Temmuz). Turkish women march in rights protest in Istanbul. Reuters. https://www.reuters.com/article/us-turkey-rights-women/turkish-women-march-in-rights-protest-in-istanbul-idUSKBNıAEOPK (Erişim Tarihi: 20 Eylül 2018).

Slee, N. (2012). Visualizing, Conceptualizing, Imagining and Praying the Christa: In Search of Her Risen Forms, Feminist Theology, 21(1), 71-90. doi: 10.1177/0966735012451831.

Sinmaz Uzgan, Y. (2018). Mutlu Toplum İnşası İçin Toplumsal Cinsiyet Eşitliği. https://www.mmo.org.tr/sites/default/files/gonderi_dosya_ ekleri/morsoylesiler.pdf (Erişim Tarihi: 22 Eylül 2018).

Smith, P. (2007). Kültürel Kuram (Çev. S. Güzelsarı \& İ. Gündoğdu). İstanbul: Babil.

Spoto, S. I. (2012). The Figure of Lilith and the Feminine Demonic in Early Modern Literature. (Yayımlanmamıs Doktora Tezi). The University of Edinburgh School of Literatures, Languages and Cultures, Edinburgh.

Stanton, E. C. (2006). The Woman's Bible. https://archive.org/stream/thewomansbibleog88ogut/wbiblıo.txt (Erişim Tarihi: 21 Eylül 2018).

Stopler, G. (2005). Gender Construction and the Limits of Liberal Equality. Texas Journal of Women and the Law, 15(43), 43-79. https:// papers.ssrn.com/sol3/papers.cfm?abstract_id=1013058 (Erişim Tarihi: 21 Eylül 2018).

Tarakçı, M. (2010). Origen ve Alegorik Kitab-1 Mukaddes Yorumu. Uludağ Üniversitesi İlahiyat Fakültesi Dergisi, 19, (1), 183-213.

Thomasset, C. (2005). Kadın Doğası (Çev. A. Fethi). C. Klapisch-Zuber (Ed.), Kadınların Tarihi II Ortaçă̆'ın Sessizliği (s. 51-74). İstanbul: Türkiye İş Bankası Kültür.

Topcan, Ö. (2010). Yahudilik ve Hristiyanllk Din Geleneklerinde Toplumsal Cinsiyet: Geleneksel Dinler Otoritesine Feminist Bakış. (Yayımlanmamış Yüksek Lisans Tezi). Ankara Üniversitesi Sosyal Bilimler Enstitüsü, Ankara.

Tokat, L. (2009). Dinin Sembolik Dili. Milel ve Nihal, 6(1), 75-98.

Ünal, A. (2017). Yahudi Geleneğinde Kadının Yaratılışı ve Lilit Efsanesi. Çukurova Üniversitesi İlahiyat Fakültesi Dergisi, 17(2), 103-115. 
Üste, R. B. (2015). Hegel-Rousseau, Mill ve Hayek'in Değerlendirmelerinde Toplumda Ötekileştirilen 'Kadın'ın Konumu. Dokuz Eүlül Üniversitesi Edebiyat Fakültesi Dergisi, 3(4), 103-126.

Venezuela protests: Women march against Maduro. (2017, 06 May1s). BBC News. https://www.bbc.com/news/world-latin-america-39828559 (Erişim Tarihi: 05 Eylül 2018).

von Trier, L. (2007). Trier On Von Trier. J. Mitchell \& B. Plate (Ed.), The Religion and Film Reader (s. 230-233). Londra: Routledge.

von Trier, L. \& Shiloh, I. (2005). Breaking the Waves; Dancer in the Dark; Dogville. Modern Language Studies, 35(1), 84-88. doi: $10.2307 / 30039812$

von Trier, L. (Yönetmen) (1996). Breaking the Waves [Film]. Danimarka: Argus Film.

Wider, K. (1986). Women Philosophers in the Ancient Greek World: Donning the Mantle. HYpatia, 1(1), 21-62. doi: 10.1111/j.15272001.1986.tbo0521.x

Wollstonecraft, M. (2012). Kadın Haklarının Gerekçelendirilmesi (Çev. D. Hakyemez). İstanbul: İş Bankası Kültür.

Wood, J. M. (2013). Patriarchy Feminism and Mary Daly: A SYstematic-Theological Enquiry Into Daly's Engagement With Gender Issues In Christian Theology. (Yayımlanmamış Doktora Tezi). University of South Africa, School of Humanities Pretoria.

Woolf, V. (2012). Kendine Ait Bir Oda (Çev. İ. Özdemir). İstanbul: Kırmizı Kedi.

Wu, H. (2017, 27 Ocak). The Day is Ours and So is the Night: Furious Indian Women Fight Back. CNN World. https://edition.cnn. com/2017/o1/26/asia/india-march-i-will-go-out/index.html (Erişim Tarihi: 05 Eylül 2018). 
